\title{
FFTF IRRADIATION OF FRACTURE MECHANICS SPECIMENS FOR OUT-OF-CORE STRUCTURES
}

DISCLAIMER Ne ther the Un ted States Government nor any agency thereof nor any of the $r$ employees makes ariy warranty express or moled or assumes any leyal labaliy or responsib ty tor discoseracy

completeness of usefuiness of any intormation appenes ants Reference here $n$ to any specifo

represents tha ts use would or ence

cot

States Gowernent or any agency therent The vews and obirions of author's expressed heren do nor 


\section{DISCLAIMER}

This report was prepared as an account of work sponsored by an agency of the United States Government. Neither the United States Government nor any agency Thereof, nor any of their employees, makes any warranty, express or implied, or assumes any legal liability or responsibility for the accuracy, completeness, or usefulness of any information, apparatus, product, or process disclosed, or represents that its use would not infringe privately owned rights. Reference herein to any specific commercial product, process, or service by trade name, trademark, manufacturer, or otherwise does not necessarily constitute or imply its endorsement, recommendation, or favoring by the United States Government or any agency thereof. The views and opinions of authors expressed herein do not necessarily state or reflect those of the United States Government or any agency thereof. 


\section{DISCLAIMER}

Portions of this document may be illegible in electronic image products. Images are produced from the best available original document. 


\section{CONTENTS}

1.0 INTRODUCTION 1

2.0 SUMMARY AND CONCLUSION

3.0 NATIONAL PROGRAM PLAN DATA REQUIREMENTS 4

4.0 IRRADIATION SPACE AND ENVIRONMENT CRITERIA 5

5.0 SURVEY OF FFTF IRRADIATION SPACE AND ENVIRONMENT

6.0 TEST VEHICLE CRITERIA $\quad 8$

7.0 PROPOSED TEST VEHICLE

7.1 MECHANICAL DESIGN 9

7.2 SCOPING EXAMPLE 13

8.0 MEETING IRRADIATION SPACE AND ENVIRONMENT CRITERIA

9.0 MEETING TEST VEHICLE CRITERIA 17

$\begin{array}{lll}10.0 & \text { POTENTIAL SCHEDULE } & 19\end{array}$

$\begin{array}{lll}11.0 & \text { REFERENCES } & 21\end{array}$

TABLES

1 REQUIRED TEST SPACE AND IRRADIATION CONDITIONS 3

2 PROPOSED SCHEDULE: FRACTURE-MECHANICS TEST ASSEMBLY 20

FIGURES

1 CONCEPTUAL FRACTURE-MECHANICS SPECIMEN TEST ASSEMBLY 11

2 CONCEPTUAL SPECIMEN HOLDER ISOMETRIC 12

3 FRACTURE MECHANICS SPECIMEN TEST ASSEMBLY WITH RELATED OPERATIONAL DATA 14

\section{APPENDIXES}

A TABLES XII AND XIII FROM THE NATIONAL PROGRAM PLAN - TC-810 A-1

$B$ INTERNAL SPECIMEN TEMPERATURE

C MOTA DIAGRAMS C-1

D NEUTRON AND GAMMA ENVIRONMENT $\quad$ D-1

E STANDARD HARDWARE E-1 
FAST FLUX TEST FACILITY IRRADIATION OF FRACTURE

MECHANICS SPECIMENS FOR

OUT-OF-CORE STRUCTURES

\subsection{INTRODUCTION}

The design and safety analys is of fast breeder reactors (FBRs) require knowledge of the effects of irradiation on out-of-core structures such as the core support structure, reactor vessel, shielding, in-vessel fuel handling equipment, piping near the reactor, guard vessel, etc. The effects of irradiation on the structural materials for the different operating conditions is only partially known; consequently, considerable conservatism is factored into the material fluence limits. For completed reactor designs or for operating reactors, additional data should allow improvement of component lifetimes for the original design conditions and for alternate fueling arrangements. For future reactors, additional data can reduce capital costs by optimizing materials selection, by extending the material fluence limits and by enabling compact structure designs for large cores.

A National Program Plan1 has been prepared which identifies the irradiation effects data required for FBR design, safety analysis and operation support. Irradiation effects data to be obtained by Fast Flux Test Facility (FFTF) irradiations were identified by comparing data in process or now available with that required.

The National Program Plan established the need for tensile, low cycle fatigue, creep-fatigue interaction, crack propagation, fracture toughness and impact types of data. The irradiation of specimens for tensile and creepfatigue properties will be largely met by Materials Open Test Assembly (MOTA) irradiations. However, MOTA irradiations can provide only a minor part of the volume required for the fracture mechanics specimen irradiations because of the large specimen sizes required to obtain appropriate (e.g., ASTM valid) fracture toughness data, the large space commitments to the National Cladding and Duct Development Program and the high gamma heating rates present in the in-core space. This report examines the feasibility 
of fulfilling the irradiation needs for these fracture mechanics specimens elsewhere in the FFTF. Speciai consideration is given to irradiation of fracture toughness specimens as large as the 1-inch thick compact tension specimens $\left[" 1 T^{\prime \prime}\left(1 " \times 2.4^{\prime \prime} \times 2.5^{\prime \prime}\right)\right]$ while limiting the internal specimen temperature differential to a maximum of $28^{\circ} \mathrm{C}\left(50^{\circ}\right)$ and still maintaining reasonable irradiation times to reach total neutron fluences of $5 \times 10^{22}$ $\mathrm{n} / \mathrm{cm}^{2}$.

\subsection{SUMMARY AND CONCLUSIONS}

The National Program Plan has established data requirements for out-ofcore structures for FBRs. Significant FFTF irradiation space with moderate gamma heating levels is required to irradiate relatively large fracture mechanics specimens to total neutron fluences ranging between $5 \times 10^{21}$ and $5 \times 10^{22} \mathrm{n} / \mathrm{cm}^{2}$ and temperatures which range between $400{ }^{\circ} \mathrm{C}$ (7500F) and $650^{\circ} \mathrm{C}$ (12000F). Priority 1 data on stainless steel welds requires a test volume of $7443 \mathrm{~cm}^{3}\left(454 \mathrm{in}^{3}\right)$. Priority 2 data on 304 and $316 \mathrm{SS}$ and Inconel 718 materials and Incone 7718 welds requires $2760 \mathrm{~cm}^{3}\left(168 \mathrm{in}^{3}\right)$. Priority 3 data on stainless steels, other nickel-base alloys, and ferritics requires $33,118 \mathrm{~cm}^{3}\left(2021 \mathrm{in}^{3}\right)$. Priority 4 data at elevated temperatures on stainless steels, other nickel-base alloys and ferritics requires 69,182 $\mathrm{cm}^{3}\left(4221 \mathrm{in}^{3}\right)$. See Table 1 for a definition of each priority level.

The feasibility of conducting the fracture mechanics irradiation in the FFTF radial reflector region has been examined using a conceptual design. The examination resulted in several conclusions:

- Non-instrumented irradiation assemblies in the FFTF radial reflector region (Rows 7 and $8 \mathrm{a}$ ) will provide an adequate irradiation vehicle for fracture mechanics specimens.

- Experimental temperatures in the 350 to $4250 \mathrm{C}$ range, can be obtained by gamma heating and coolant flow control; however, higher temperatures may require gas-gapped capsules or other special arrangements. 
TABLE 1

REQUIRED TEST SPACE AND IRRADIATION CONDITIONS




- A maximum allowable temperature gradient within specimens of about $280 \mathrm{C}$ (500F) limits gamma heating rates to about 1.0 watts/gram for the " $1 T$ " compact tension specimen. Gamma heating rates greater than 3 watts/gram are allowable for smaller specimens.

- Priority $1,2,3$, and 4 irradiations can be satisfied by the equivalent of $1.3,0.2,6.0$ and 12.0 irradiation-vehicle-cycles respectively. These equivalent irradiation-vehicle-cycles are derived by assuming irradiation assembly locations and specimen placements within those assemblies to achieve $5 \times 10^{21} \mathrm{n} / \mathrm{cm}^{2}$ fluence in one cycle and $5 \times 10^{22} \mathrm{n} / \mathrm{cm}^{2}$ fluence in four cycles.

\subsection{THE NATIONAL PROGRAM PLAN}

The National Program Plan identifies the requirements for irradiation effects data for design, operations support, and safety analyses of FBRs. A specimen irradiation program is recommended to provide that data not now available or in process. This implementation study relates to the crack propagation, fracture toughness, and impact properties portion of the overall National Program Plan. The required data is identified in Table XII, "Recommended Program, Fatigue-Crack Propagation," Page 96 and Table XIII, "Recommended Program, Fracture Toughness," Page 97. These two tables are included as part of Appendix $A$ to this document. In general, the data at $400^{\circ} \mathrm{C}$ (750 $\mathrm{F}$ ) has the highest priority. At this temperature, the austenitic weldments are a Priority 1, and the Inconel and annealed austenitic base metal have the second order of priority (Priority 2). The rest of the data at the $400^{\circ} \mathrm{C}$ columns is Priority 3 . In general, the other data at $538^{\circ} \mathrm{C}(1,000 \mathrm{OF})$ and $6500 \mathrm{C}$ (12000F) columns, is considered Priority 4.

The specimen size and numbers required for each data point are defined in "Fracture Mechanics Testing Criteria for FFTF Irradiations and Post Irradiation Testing." 2 
Determination of each fracture toughness data point requires five to six test specimens plus a tensile specimen. The austenitic stainless steel and feritic steels require "1T" $(2.54 \mathrm{~cm} \times 6.1 \mathrm{~cm} \times 6.35 \mathrm{~cm})$ specimens while the high strength precipitation-hardened alloys require "0.577T" $(1.466 \mathrm{~cm} \times 3.52$ $\mathrm{cm} \times 3.66 \mathrm{~cm}$ ) specimens. Fatigue crack propagation specimens will have similar dimensions but will be thinner. Two fatigue crack propagation specimens are required for each environmental condition.

Impact specimens are relatively small as compared to the fracture toughness specimens and thus the volume they would occupy is accounted for in the packing factor. The volume for the tensile specimen that must accompany fracture toughness specimens for each data point is treated similarly.

Table I was prepared from the National Program Plan, Tables XII and XIII. This information was used to obtain an initial estimate of the irradiation test volumes required by the plan. Priority 1 data requires a test volume of $7443 \mathrm{~cm}^{3}\left(454 \mathrm{in}^{3}\right)$, Priority 2 data requires $2760 \mathrm{~cm}^{3}\left(168 \mathrm{in}^{3}\right)$, and Priority 3 data requires $33,118 \mathrm{~cm}^{3}$ (2021 in $\left.{ }^{3}\right)$. Satisfying all data requirements would require $112,503 \mathrm{~cm}^{3}\left(6865 \mathrm{in}^{3}\right)$.

\subsection{IRRADIATION SPACE AND ENVIRONMENT CRITERIA}

The basic criteria are provision for the space and environment to irradiate specimens to fulfill the requirements of the National Program Plan (Tables XII and XIII). The specific criteria items to define the considerations employed in this study are:

4.1 Fracture toughness specimens are two sizes, "0.577T" and "1T" (compact tension specimens).

4.2 Crack propagation specimens will have the same planar dimensions as fracture toughness specimens but with $1 / 4$ to $1 / 3$ of the thicknesses.

4.3 At least 30 "1T" specimens should be accommodated in each test assembly. 
4.4 The test vehicle should be compatible for installation in a variety of neutron fluxes to accommodate the needs of various test trains. Neutron fluxes should range from as high as possible to achieve fluences of $5 \times$ $10^{22} \mathrm{n} / \mathrm{cm}^{2}$ in as few cycles as possible (consistent with allowable specimen internal temperature gradients) to neutron fluxes which will achieve fluences of $5 \times 10^{21} \mathrm{n} / \mathrm{cm}^{2}$ in not less than 1.0 cycles.

4.5 The gamma heating rates should not exceed 1.0 watts/gram for "1T" specimens to limit the specimen total internal temperature gradient to less than $280 \mathrm{C}$ (500F). For ".577T" specimens, the 1 imit should be 3.0 watts/gram.

4.6 Temperature control and monitoring should be passive.

4.7 Assembly design options should permit the specimens to be irradiated for data at the three temperatures of $400^{\circ} \mathrm{C}$ (750 $\left.\mathrm{F}\right), 538^{\circ} \mathrm{C}\left(1000^{\circ} \mathrm{F}\right)$, and $6500 \mathrm{C}(12000 \mathrm{~F})$. (Note: For a single test assembly with passive temperature control, there probably will be a range of specimen temperatures).

4.8 Specimen groups are to be removed and replaced between cycles but no Inter im Examination and Maintainence Facility (IEM Cell) measurements are required.

4.9 Specimens of various sizes and shapes in addition to those identified in Section 4.1 of this document are to be accommodated.

4.10 Assembly positions with outlet temperature monitors are desired. Passive temperature sensors (TEDs, melt sentinels, etc.) will be used to monitor specimen surface and internal temperatures.

\subsection{SURVEY OF FFTF IRRADIATION SPACE AND ENVIRONMENT}

The "Fracture Mechanics Testing Criteria for FFTF Irradiation and Post Irradiation Testing,". set a maximum allowable internal specimen temperature difference of $28^{\circ} \mathrm{C}\left(50^{\circ} \mathrm{F}\right)$ for the " $1 \mathrm{~T}^{\prime}$ specimens. This limits the available test positions to areas that have peak gamma heating rates below 1.0 
watts/gram (Appendix B). This means that irradiation must occur outside the fueled region. (Note: "0.577T" specimens are controlled by the $280^{\circ} \mathrm{C}$ limit to a maximum gamma heating rate of 3.0 watts/gram. Mixed specimen loadings with "0.577T" specimens in the peak flux zone would also make positions with higher gamma heating rates acceptable.)

The space above or below the fueled region of the core is limited both in volume and irradiation conditions; that is, the flux changes rapidly with axial position, volume of space available, and outlet temperatures. The schedules will be dictated by the in-core experiment or use. For example, the MOTA has space $20 \mathrm{~cm}$ (8") long immediately below the core where the flux is too high for the $5 \times 20^{21}$ fluence requirement and the gamma heat exceeds 1.0 watt/gram. See Appendix $C$ for diagrams of a typical MOTA. MOTA also has space starting $53 \mathrm{~cm}$ (21") above the top of the core, but the neutron flux is too low and the temperature is limited to the outlet temperature. Therefore, MOTA can provide only limited space with very restricted irradiation conditions for the larger structural materials fracture mechanics specimens. Oniy one fracture toughness data point can be realized in MOTA per 1.5 years irradiation. Less than one half of the Priority 1 and 3 data points (generally $4000^{\circ} \mathrm{C}, 5 \times 10^{22} \mathrm{n} / \mathrm{cm}^{2}$ data) could be realized using this facility. Over a nine-year period, MOTA would provide less than 10 percent of the required program data.

The radial reflectors provide very desirable test space. Each of the 108 radial reflector positions has potentially $12,798 \mathrm{~cm}^{3}\left(780 \mathrm{in}^{3}\right)$ of space over a $122 \mathrm{~cm}$ (48") length. For low temperature irradiations, up to 48 "1T" specimens could be accommodated in one test vehicle with a 37 percent volume packing fraction (specimen volume/total volume). The radial reflector positions offer centerline neutron fluxes ranging from $2.0 \times 10^{15} \mathrm{n} / \mathrm{cm}^{2} \mathrm{sec}$ to $0.5 \times 10^{15} \mathrm{n} / \mathrm{cm}^{2} \mathrm{sec}$ (Appendix D). The gamma heating levels corresponding to these neutron fluxes are expected to be $1.3 \mathrm{w} / \mathrm{g}$ and $0.3 \mathrm{w} / \mathrm{g}$, respectively (Appendix D). Specimen irradiation temperatures can be controlled by the average gamma heating, vertical position of the specimen, metal-to-sodium ratio, and sodium flow. The sodium flow is controlled by the or ifice size in the inlet nozzle of the assembly and can provide a wide range 
of temperatures; however, the highest temperature tests will likely require insulated specimens. The optimum design for the higher temperature tests and the related packing factor determination have not been completed at this time other than to show feasibility.

The radial reflector positions provide good irradiation volume per assembly, considerable variation in flux, and a spectrum that is softer than that of the core but hard (conservative) when compared to out-of-core structures. The radial reflector positions are the outer three rows, Rows 7,8 , and 9, as shown in Appendix D. All Row 7 positions have assembly out let temperature thermocouples and 12 of the Row 7 positions have assembly flow meters. Appendix $E$ shows a radial reflector being lowered into position during the original core assembly and before the simulated fuel assemblies are installed. Refer to "FFTF, System Design Description for Reactor System,"3 for additional radial reflector design information.

\subsection{TEST VEHICLE CRITERIA}

As a guide to designing a test vehicle for a radial reflector position, several interim design criteria have been established:

\subsection{Standard hardware should be used.}

6.2 The design is to be usable in a variety of test locations and fluxes.

6.3 The ducted test vehicle must interface with the in-core fuel handling equipment, core basket, and adjacent core assemblies.

6.4 Sodium flow must be maintained to adequately cool the vehicle structure and specimens; provide the desired specimen temperatures; and assure that stress levels in the structure, instrument tree, and adjacent assembly are not excessive.

6.5 The test vehicle and test train must not significantly degrade the neutron reflection capability of the total reflector. 
6.6 The test vehicle and test train in conjunction with other reflector experiments must maintain the shielding capability of the total reflector.

6.7 The radiation induced swelling of the vehicle and the vehicle relative stiffness must be compatible with the core restraint action.

6.8 Test vehicle insertion and removal forces must be compatible with the in-vessel fuel handling equipment capability.

6.9 There will be no credible potential for parts and materials to become dislodged from the test assembly.

6.10 The vehicle must interface with the out-of-reactor fuel handling equipment.

6.11 The vehicle and test train must interface with the IEM Cell and equipment for specimen removal and reinsertion.

6.12 The vehicle and test train must be designed for ease of handling in the IEM Cell while minimizing the potential for specimen spilling or dropping. Turnaround time in the IEM Cell should be minimal.

\subsection{PROPOSED TEST VEHICLE}

\subsection{Mechanical Design}

The radial reflector assembly design is not readily adaptable to modification for the irradiation of large test specimens; however, the hexagonal duct design of fixed shims, in-core shims, and fuel elements is adaptable. The ducted assembly standard hardware also readily adapts for use in the radial reflector locations. In fact, the fixed shim is designed for and used in Row 7. Other ducted assembly experiments are proposed for the radial reflector positions. Appendix $E$ shows a sketch of a ducted assembly and some photographs of standard hardware. 
Figures 1 and 2 show some details of one possible conceptual design. The standard duct has an inside dimension across the flats of $11.01 \mathrm{~cm}(4.335$ in) which gives $105 \mathrm{~cm}^{2}\left(16.27 \mathrm{in}^{2}\right)$ of cross section for the specimens, specimen holder hardware, and any added structure. The radial reflector nozzle and shield/orifice assemblies for inner (Rows 7 and 8a) or outer (Rows $8 \mathrm{~b}$ and 9) reflectors should be used with proper orificing for the desired test temperature. The new replacement reflector design includes a feature that permits orifice plates to be changed easily prior to irradiation. This feature should be incorporated.

A removable handling socket can be used to facilitate specimen removal and replacement. A removable socket is shown in Appendix $E$ with a fixed load pad; a floating load pad could also be considered. An alternate to the removable handling socket design, which may be consistent with reflector assembly life due to radiation swelling, would be to sacrifice the vehicle and reload into a new vehicle for specimen reloading. The IEM Cell has the capability to make the duct weld remotely. The IEM Cell is probably capable of slitting a bowed duct to permit removal; however, this process has not been demonstrated on a duct. If a removable socket is used, the test train could be attached to the socket and removed as a unit. An alternate design would utilize a duct-to-nozzle slip fit and remove the duct with the handling socket, leaving the test train with the nozzle. The socket and nozzle in this design would be connected structurally by members internal to the duct.

The specimen holders could be any vertical length for convenience; however, a $7.62 \mathrm{~cm}$ ( $3 \mathrm{in}$ ) high holder would be ideal for containing three " $1 \mathrm{~T}$ " specimens and a stack of 16 holders would then make a $122 \mathrm{~cm}(48$ in) test train. The holder cross section would otherwise be shaped to fit within the vertical structural members while still maintaining space for three "1T" specimens. The holders should nest with each other and within the structure and only be removable individually at specific structural elevations. The holder should also be shaped to allow firm positive gripping by IEM Cell equipment for insertion and removal. 


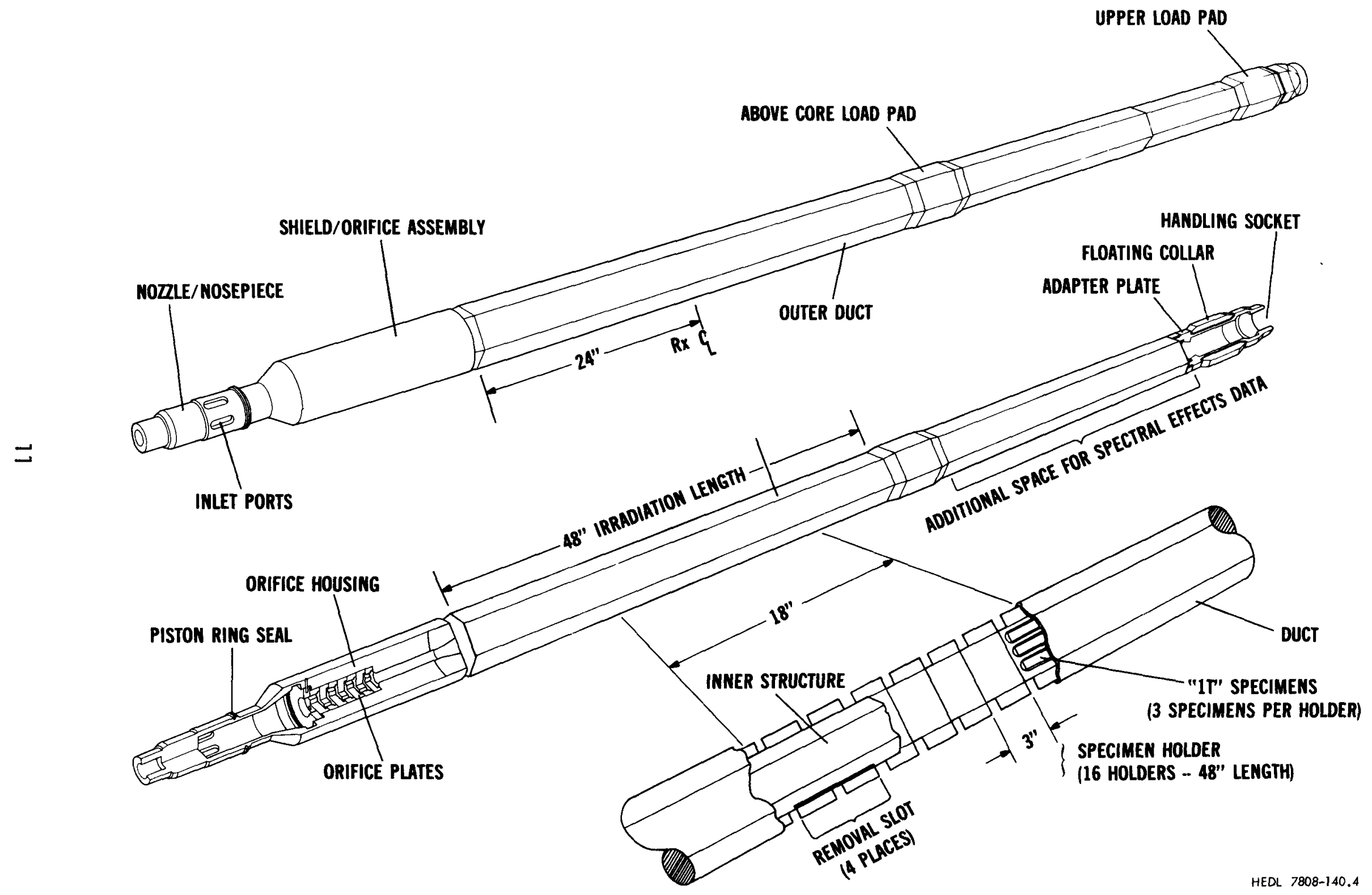

FIGURE 1. Conceptual Fracture-Mechanics Specimen Test Assembiy. 


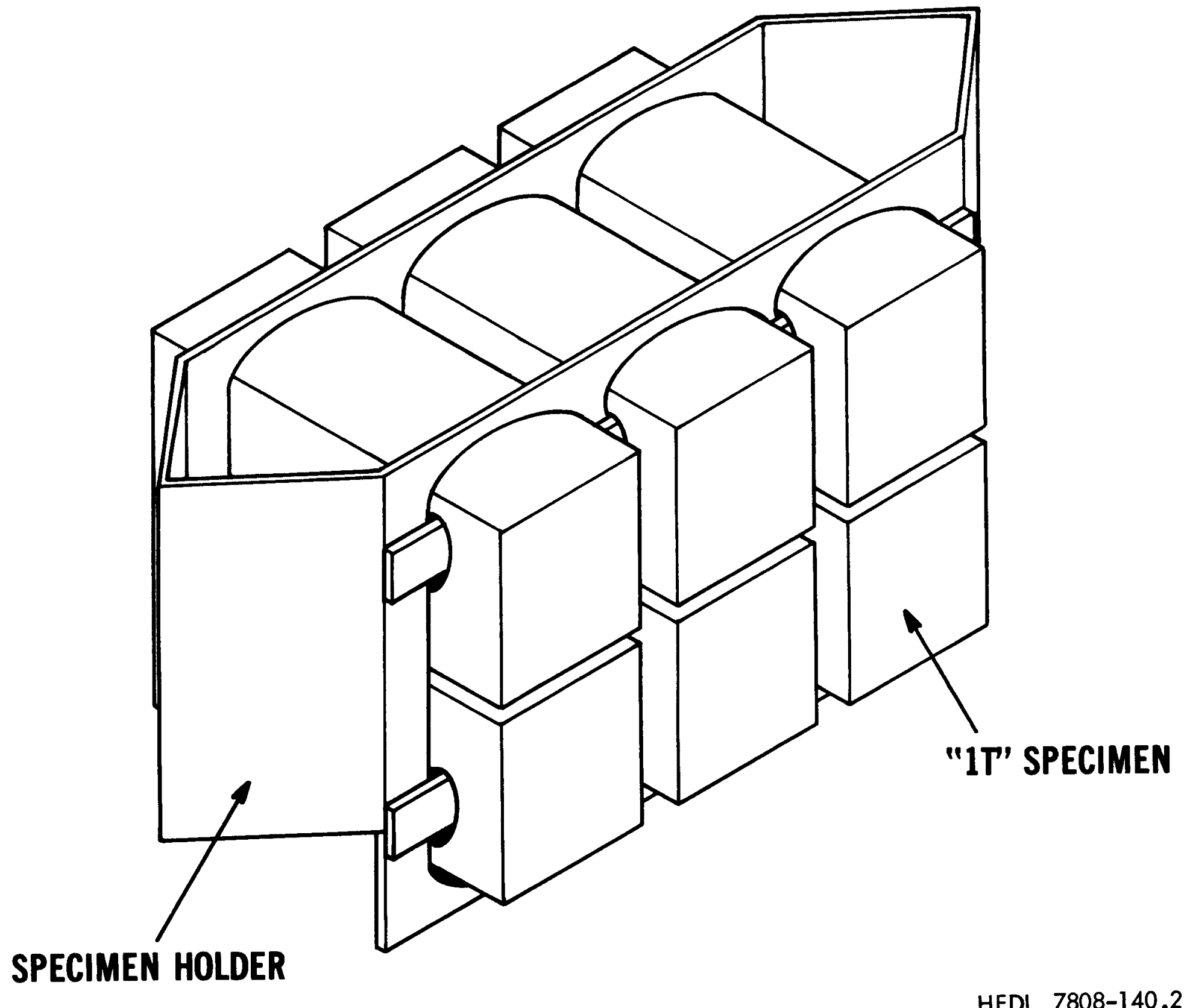

HEDL $7808-140.2$

FIGURE 2. Conceptual Specimen Holder Isometric. 


\subsection{The Scoping Example}

The priority needs are for specimens irradiated at temperatures in the $400^{\circ} \mathrm{C}$ (7500F) regime with special emphasis on "1T" size specimens; so, for scoping, a test train consisting of $48^{\prime \prime} 1 \mathrm{~T}$ " specimens operating with a $4270 \mathrm{C}$ (8000F) outlet temperature is analyzed. The FFTF core inlet temperature is $3600 \mathrm{C}$ (6800F).

It has been determined that " $1 \mathrm{~T}$ " specimens will exceed $28^{\circ} \mathrm{C}$ (500F) internal temperature gradients if the gamma heating rate exceeds 1.0 watt/gram (Appendix B). It would be desirable to find the highest flux position available having this heating rate; however, it appears that positions with this maximum will have a total neutron flux of $1.5 \times 10^{15} \mathrm{n} / \mathrm{cm}^{2} \mathrm{sec}$ (Appendix D). For this study, these values are used for the maximum centerline values rather than those of the specimens closest to the core. Corner Row 7 positions and Row 8a positions are likely candidate locations for this neutron flux (Appendix D). Figure 3 shows an example of the operating environment experienced by a test train of 48 " $1 \mathrm{~T}$ " specimens inserted into a radial reflector position that has a maximum centerline gamma heating rate of $1.0 \mathrm{w} / \mathrm{g}$ and is orificed for a flow of $5,225 \mathrm{lb} / \mathrm{hr}$. The gamma flux profile was assumed to be identical to the neutron profile and the assembly power calculated assuming that the volume fractions are:

Stainless Steel

Duct $10 \%$

Specimens $40 \%$

Specimen Holders $3 \%$

Internal Structure

Sodium $17 \%$ $30 \%$

Note: The net heat transfer to adjacent assemblies was assumed to be 0.0 .

Figure 3, intended for scoping and planning purposes only, can be used to determine the test environment of each specimen. Specific vehicle and test train designs coupled to neutron and gamma profiles for a specific position and specific fuel and experiment loading are required for a more accurate estimate. 


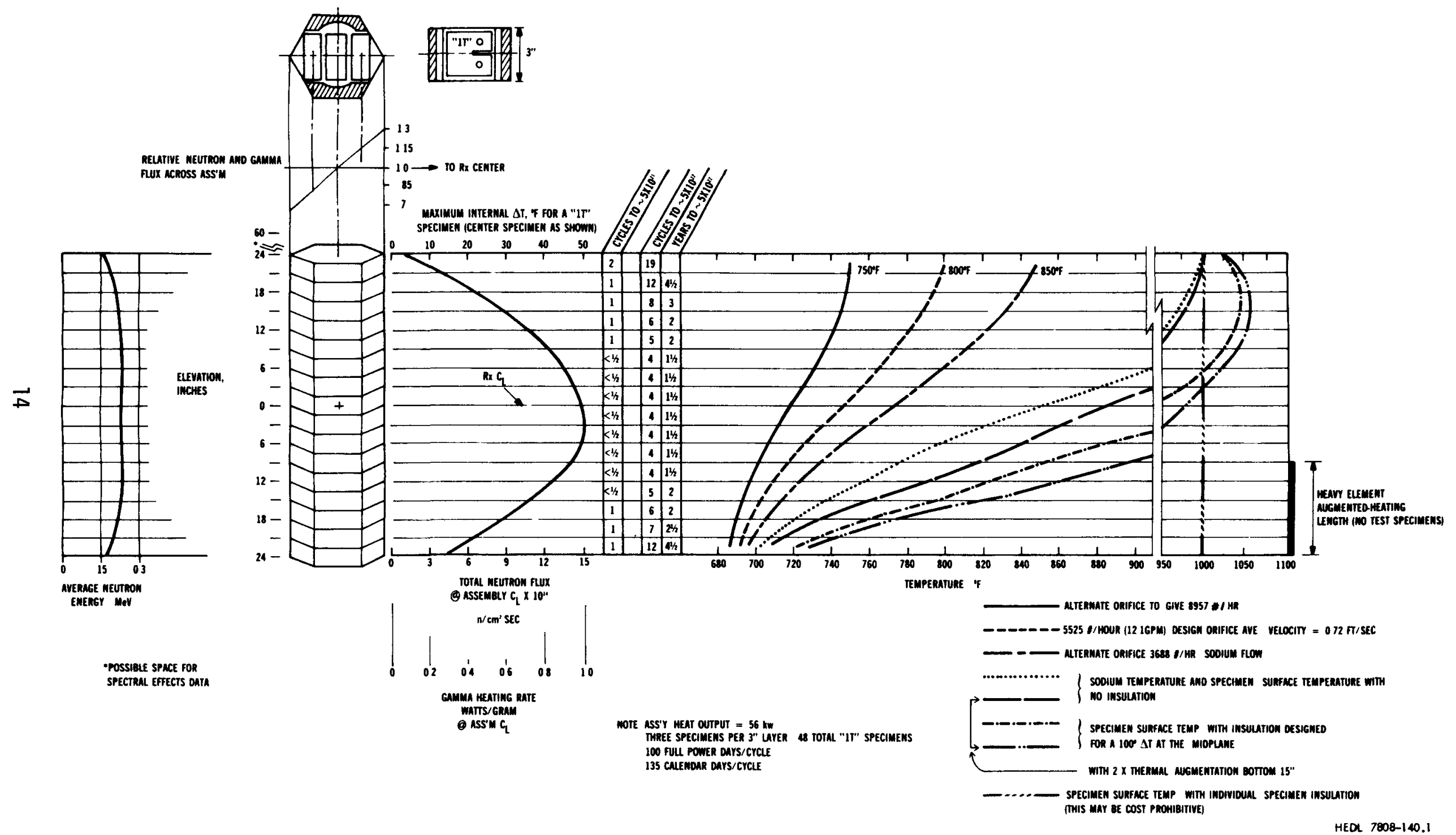

FIGURE 3. Fracture Mechanics Specimen Test Assembly with Related Operational Data. 


\subsection{MEETING IRRADIATION SPACE AND ENVIRONMENT CRITERIA}

Each of the irradiation space and environment criteria items is discussed in this section. For easy reference, the items are numbered the same as in Section 4.0 herein.

\section{(4.1 \& 4.2) The "1T" Specimen Size}

The " $1 T$ " specimen size can be irradiated in the FFTF radial reflectors as long as they are positioned in gamma fluxes below $1 \mathrm{w} / \mathrm{g}$.

\section{Specimens/Assembly}

For the lower temperature runs, it appears a maximum of 48 " $1 \mathrm{T"}$ specimens can be handled. For higher temperature operation, it may be necessary to insulate the specimens which would probably reduce the total number to 32.

\section{(4.4) Fluences}

Figure 3 indicates that fluences in the range of $5 \times 10^{21} \mathrm{n} / \mathrm{cm}^{2}$ or less can be achieved for 24 specimens in one cycle for the reflector position in the example. Lower flux positions could be selected for an assembly designed specifically for lower fluence data. Figure 3 also indicates that possibly 21 "1T" specimens/assembly can reach fluences of $5 \times 10^{22} \mathrm{n} / \mathrm{cm}^{2}$ in $1-1 / 2$ years and that 33 specimens/assembly can achieve $5 \times 10^{22} \mathrm{n} / \mathrm{cm}^{2}$ in two years. Loadings with "0.577T" specimens at higher gamma heating elevations can be located to achieve fluences of $5 \times 10^{22} \mathrm{n} / \mathrm{cm}^{2}$ in two cycles (eight months). Although it has not been studied in detail, it is possible that a material like tungsten could be used to shield the specimens from the core gamma flux allowing the assembly to be placed in a higher neutron flux position at some sacrifice of test space. The design can be adapted for location in any radial reflector position. The only difference between inner and 
outer reflector positions would be the nozzle assembly. However, each assembly must be orificed for its specific location and temperature requirements.

\section{(4.5) $280 \mathrm{C}$ Internal Specimen Temperature Difference Limit}

As noted previously, it appears that if the gamma heating rate is below $1 \mathrm{w} / \mathrm{g}$, then the $280 \mathrm{C}$ (500F) limit will not be exceeded for "1T" specimens and $3 \mathrm{w} / \mathrm{g}$ for "0.577T" specimens.

\section{(4.6) Passive Temperature Control}

Passive temperature control is realistic for at least the lower temperature specimens and probably for the insulated specimens also.

\section{(4.7) Temperature Regimes}

This study concentrated on the high priority low temperature data; but, it appears that reduced flows for intermediate temperatures and reduced flows plus augmented gamma heating using high density material (e.g. tungsten) as well as insulated specimen holders are feasible techniques for the high temperature irradiations.

(4.8) Interim Specimen Removal

The design concept permits removal and replacement of groups of three specimens at a time.

\section{(4.9) Random Shape Specimens}

The design concept would permit irradiating specimens smaller than the "1T" size. 


\section{(4.10) Temperature Monitoring}

TEDs or melt sentinals will be used to monitor temperatures. The 1 w/g limit could restrict the ability to operate the assembly in Row 7; however, that does not appear to be the case. Using smaller specimens in the assembly high gamma heating eleveations could be an option.

\subsection{MEETING TEST VEHICLE CRITERIA}

Each of the test vehicle criteria items is discussed in this section. For easy reference, the items are numbered the same as in Section 6.0 .

\section{(6.1) Standard Hardware}

Standard hardware is used.

\section{(6.2) Variety of Locations}

The design concept proposed appears usable in any position. Each assembly with its test train must be or ificed for a specific gamma heating rate and must use a nozzle for either an inner or outer position.

\section{(6.3) In-Core Interface}

Since the outer configuration is standard hardware, it has outside contacting surface dimensions identical to other core components and thus is compatible. The steep thermal and neutron gradients in the reflectors will cause radiation induced swelling bow and thermal bow. This bow, coupled with the structurally stiffer ducted assembly (as compared to the standard radial reflector assemblies), must be evaluated; however, there are design options including a test vehicle design life limit which can be used to make the interface acceptable. The fixed shims are Row 7 ducted assemblies which have the same considerations. 


\section{(6.4) Sodium Flow}

The test assembly has less mass than a standard radial reflector assembly and thus will produce less heat. The test assembly also can be orificed for higher flow than a standard radial reflector assembly. This means that adequate flow is available for cooling. The sodium flow can be distributed to provide optimum flow for each specific test train design.

\section{Neutron Reflection}

From a neutron reflection standpoint, the effect of a fracture mechanics assembly will be within the normal core loading adjustments for the experimental loadings and much less than the effect of a fixed shim. The specific assembly design analysis will address these considerations in more detail.

\section{(6.6) Shielding}

The reflectors are designed for a high Inconel to sodium ratio. The test assembly will have a lower ratio and thus a lower shielding and reflecting capability. From a shielding standpoint, a Row 7 fracture mechanics assembly will impose less of a burden on the reactor structural materials than a Row 7 HEFA or Radial Blanket Test Assembly even if the volume ratio is only 0.30 to 0.40 . However, void spaces in the assembly can be filled with Inconel to improve the ratio if required.

\section{(6.7) Swelling and Stiffness}

The ducted assembly is stiffer than a standard reflector and has steeper thermal and neutron gradients than a core ducted assembly. These features can cause more serious bow problems, but the features are identical to the fixed shim and other proposed Row 7 ducted assemblies. However, this must be considered in more detail. 
(6.9) Loose Material and Parts

The design concept will prevent material and parts from becoming dis lodged.

(6.10) Out-of-Reactor Equipment Interface

The use of standard hardware assures that the vehicle will interface with fuel handling equipment.

(6.11) IEM Ce11 Interface

This interface has not been investigated in detail, but the design concept appears to achieve this goal.

10.0 POTENTIAL SCHEDULE

Table 2 is a schedule for a Cycle 2 insertion of a radial reflector test assembly consisting of 48 " $1 \mathrm{~T}$ " specimens operating in the $750^{\circ} \mathrm{F}$ temperature regime. 
TABLE 2

PROPOSED SCHEDULE

FRACTURE-MECHANICS TEST ASSEMBLY

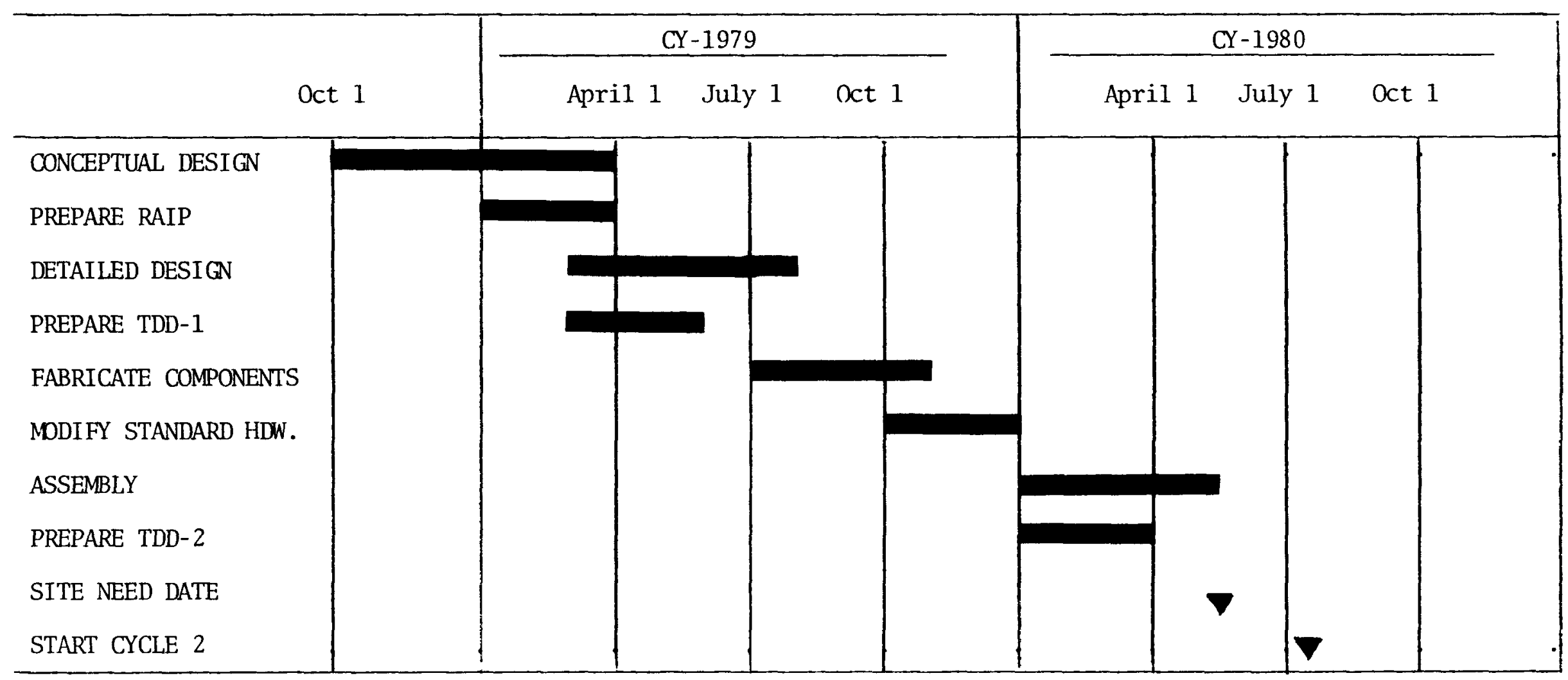

RAIP - Request for Approval in Principle

TDD - Test Design Description 


\subsection{REFERENCES}

11.1 "National Program Plan, Irradiation Effects on the Mechanical Properties OK of LMFBR Structural Materials," TC-810, Hanford Engineering Development Laboratory, Richland, WA, March 1, 1977.

11.2 L. A. James, "Fracture Mechanics Testing Criteria for FFTF Irradiations and Post Irradiation Testing, TC-1227, "Hanford Engineering Development Laboratory, Richland, WA, August 1978.

11.3 "FFTF, System Design Description for Reactor System," SDD-31, Hanford Engineering Development Laboratory, Richland, WA. 
APPENDIX A

TABLES XII AND XIII FROM THE NATIONAL

PROGRAM PLAN - TC-810

A-1 


\section{CONTENTS}

Page

$$
\begin{aligned}
& \text { "National Program Plan, Irradiation Effects } \\
& \text { On The Mechanical Properties of the LMFBR } \\
& \text { Structural Materials," TC-810, March 1, } 1977 .
\end{aligned}
$$

\section{Tab le}

1 Table XII, "Recommended Program, Fatigue Crack

Propagation," Page 96

A-3

2 Table XIII, "Recommended Program, Fracture

Toughness," Page 97

A-4 
TABLE 1 (XII)

\section{RECOMMENDED PROGRAM}

\section{FATIGUE-CRACK PROPAGATION}

Approximate Fluence Levels Required in a Given Temperature Regime

Annealed 304 SS

Annealed 316 SS

$304 / 308$ Weldments

316 Weldments ( 316 filler)

316 Weldments (16-8-2 filler)

Inconel 718 (CHT)

Incone 1718 (INEL)

Inconel 718 welds (CHT)

Inconel 718 Welds (INEL)

A-286 Stee 1

Incone 1600

CF8 Castings

Primary Ferritic Stee 1

Primary Ferritic Welds

Alternate Ferritic Steel(s)

Alternate Ferritic Welds

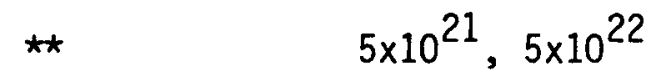

**

$\star \star$

$5 \times 10^{22}$

$5 \times 10^{21}, 5 \times 10^{22}$

$\star \star$

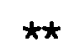

$5 \times 10^{21}$ *

$5 \times 10^{21}$ *

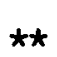

$\star \star$

**

$5 \times 10^{21}, 5 \times 10^{22}$

$5 \times 10^{21}, 5 \times 10^{22}$

$5 \times 10^{21}, 5 \times 10^{22}$

$5 \times 10^{21}, 5 \times 10^{22}$
$5 \times 10^{21}, 5 \times 10^{22}$

$5 \times 10^{21}, 5 \times 10^{22}$

$5 \times 10^{21}, 5 \times 10^{22}$

$5 \times 10^{21}, 5 \times 10^{22}$

$5 \times 10^{21}, 5 \times 10^{22}$

$5 \times 10^{21}, 5 \times 10^{22}$

$5 \times 10^{21}, 5 \times 10^{22}$

$5 \times 10^{21}, 5 \times 10^{22}$

$5 \times 10^{21}, 5 \times 10^{22}$

$5 \times 10^{21}, 5 \times 10^{22}$

$5 \times 10^{21}, 5 \times 20^{22}$

$5 \times 10^{21}, 5 \times 10^{22}$

$5 \times 10^{21}$

$5 \times 10^{21}$

$5 \times 10^{21}$

$5 \times 10^{21}$

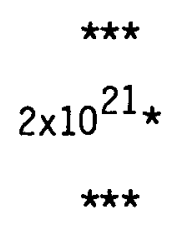

$2 \times 10^{21}, 5 \times 10^{22}$

$2 \times 10^{21}, 5 \times 10^{22}$

$5 \times 10^{21}$

$5 \times 10^{21}$

$5 \times 10^{21}, 5 \times 10^{22}$

$5 \times 10^{21}, 5 \times 10^{22}$

$5 \times 10^{21}, 5 \times 10^{22}$

$5 \times 10^{21}, 5 \times 10^{22}$

$\star \star \star$

$\star \star \star$



$\star \star \star$

$\star \star \star$ 
TABLE 2 (XIII)

\section{RECOMMENDED PROGRAM}

FRACTURE TOUGHNESS

Approximate Fluence Levels Required in a Given

\section{0}

Annealed 304 SS

Annealed 316 SS

304/308 Weldments

316 Weldments (316 filler)

316 Weldments (16-8-2 filler)

Inconel 718 (CHT)

Incone 718 (INEL)

Inconel 718 Welds (CHT)

Inconel 718 Welds (INEL)

\section{A-286 Stee 1}

Inconel 600

CF8 Castings

Primary Ferritic Steel

Primary Ferritic Welds

Alternate Ferritic Steel(s)

Alternate Ferritic Welds

$$
5 \times 10^{21} \star
$$$$
5 \times 10^{21} \text { * }
$$$$
5 \times 10^{21} \text { * }
$$$$
5 \times 10^{21}, 5 \times 10^{22}
$$$$
5 \times 10^{21}, 5 \times 10^{22}
$$$$
\star \star
$$$$
\star \star
$$


$\star \star$

$$
5 \times 10^{21} \text { * }
$$$$
5 \times 10^{21} \text { * }
$$

$5 \times 10^{21}, 5 \times 10^{22}$

$5 \times 10^{21}, 5 \times 10^{22}$

$5 \times 10^{21}, 5 \times 10^{22}$

$5 \times 10^{21}, 5 \times 10^{22}$

\section{$1000^{\circ} \mathrm{F}$}

$$
5 \times 10^{21}, 5 \times 10^{22}
$$

$5 \times 10^{21}, 5 \times 10^{22}$

$5 \times 10^{21}, 5 \times 10^{22}$

$5 \times 10^{21}, 5 \times 10^{22}$

$5 \times 10^{21}, 5 \times 10^{22}$

$5 \times 10^{21}, 5 \times 10^{22}$

$5 \times 10^{21}, 5 \times 10^{22}$

$5 \times 10^{21}, 5 \times 10^{22}$

$5 \times 10^{21}, 5 \times 10^{22}$

$5 \times 10^{21}, 5 \times 10^{22}$

$5 \times 10^{21}, 5 \times 20^{22}$

$5 \times 10^{21}, 5 \times 10^{22}$

$5 \times 10^{21}$

$5 \times 10^{21}$

$5 \times 10^{21}$

$5 \times 10^{21}$

\section{$1200^{\circ} \mathrm{F}$}




\section{APPENDIX B}

INTERNAL SPECIMEN TEMPERATURES

B-1 


\section{CONTENTS}

Page

Assumptions

B-3

\section{Figure}

1. $\Delta T$ as a Function of Specimen Size (Radial Reflector B-4 Row 7 Position - Reactor Midplane)

2. $\triangle T$ as a Function of Specimen Size (Radial Reflector Row $7 \quad$ B-5 Position: -20 Inches from Reactor Midplane)

3. $\triangle T$ as a Function of the Distance from Midplane (0.577T Specimen B-6 in Row 7 Position)

4. $\triangle \mathrm{T}$ as a Function of the Distance from Midplane (1.00" Specimen B-7 in Row 7 Position)

5. $\Delta \mathrm{T}$ as a Function of the Distance from Midplane (1.25" Specimen B-8 in Row 7 Position) 


\section{ASSUMPTIONS:}

The graphs included in this Appendix were prepared by J. M. Grover, HEDL. Several plots of internal specimen temperature differences versus position for three sizes of specimens in a row 7 radial reflector position were calculated using these assumptions:

- Peak garma heat is 1.15 watts/gram $\pm 50 \%$

- The specimen has an isothermal boundary of $800^{\circ} \mathrm{F}$ on all faces

- Heat generation is uniform throughout the spec imen

- Convection was not considered 




FIGURE 1. $\triangle$ T as a Function of Specimen Size (Radial Reflector Row 7 Position Reactor Midplane), 


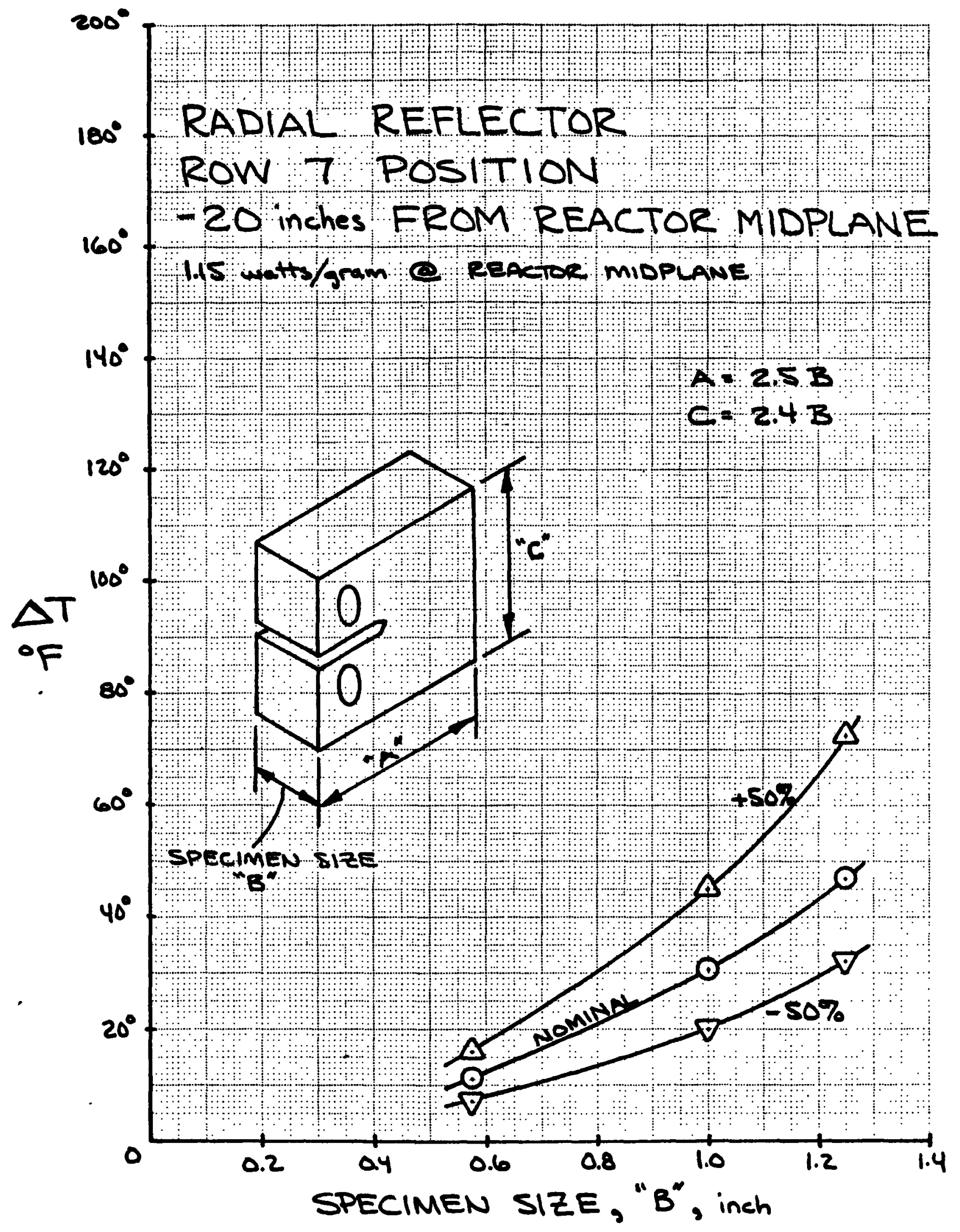

FIGURE 2. $\triangle T$ as a Function of Specimen Size (Radial Reflector Row 7 Position: -20 Inches from Reactor Midplane). 


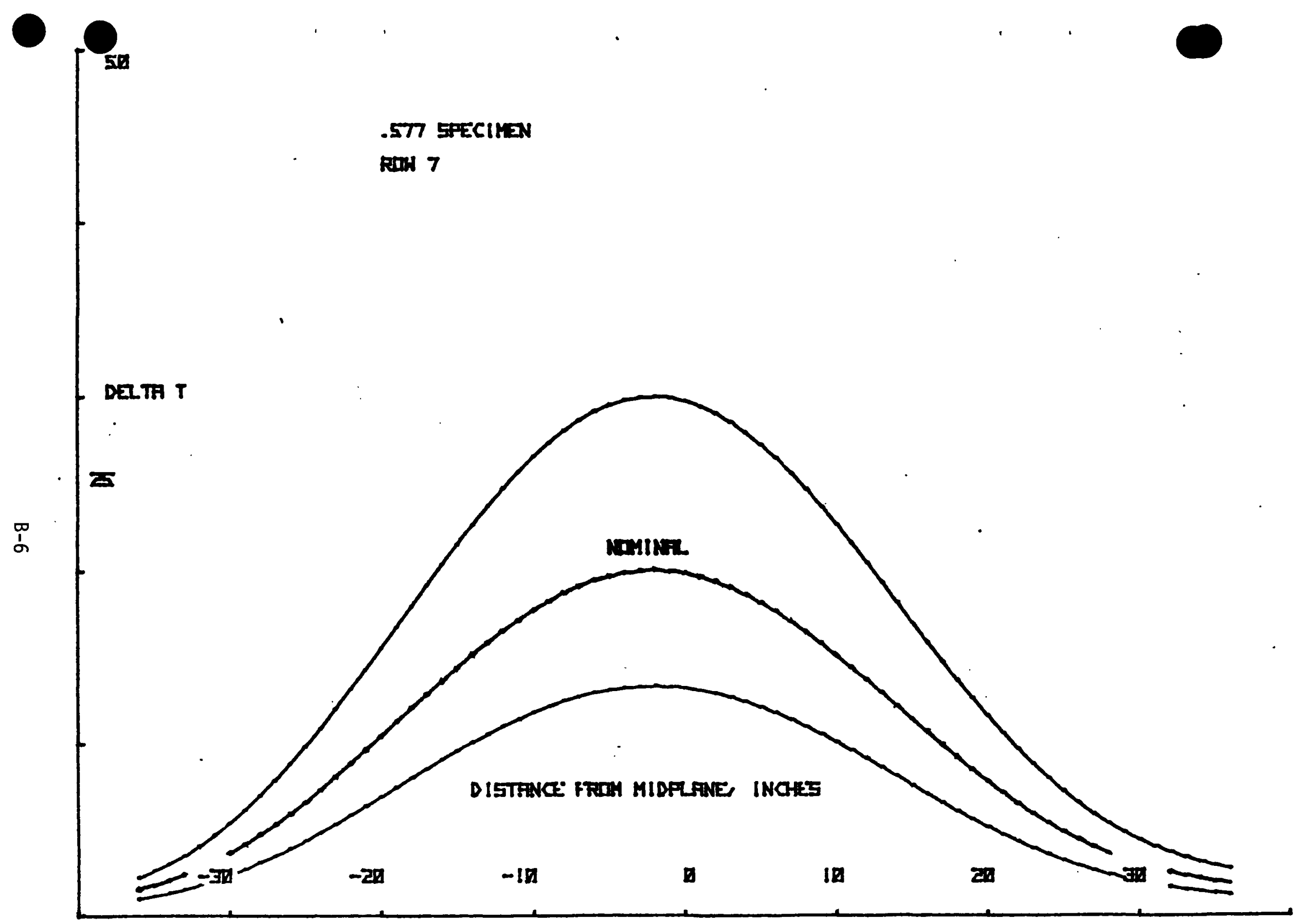

FIGURE 3. $\triangle T$ as a Function of the Distance from Midplane (0.577T Specimen in Row 7 Position). 


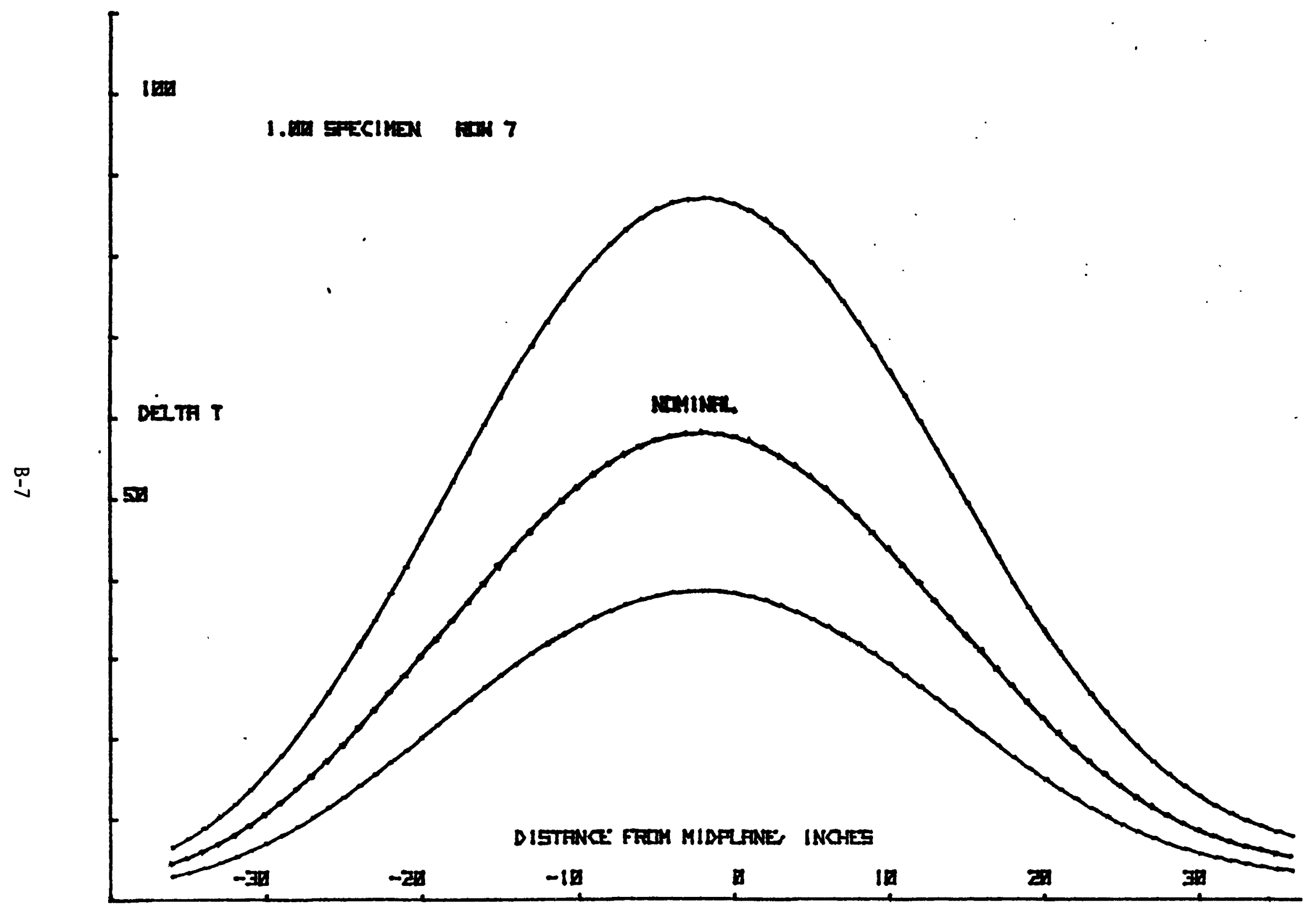

FIGURE 4. $\triangle T$ as a Function of the Distance from Midplane (1.00" Specimen in Row 7 Position). 


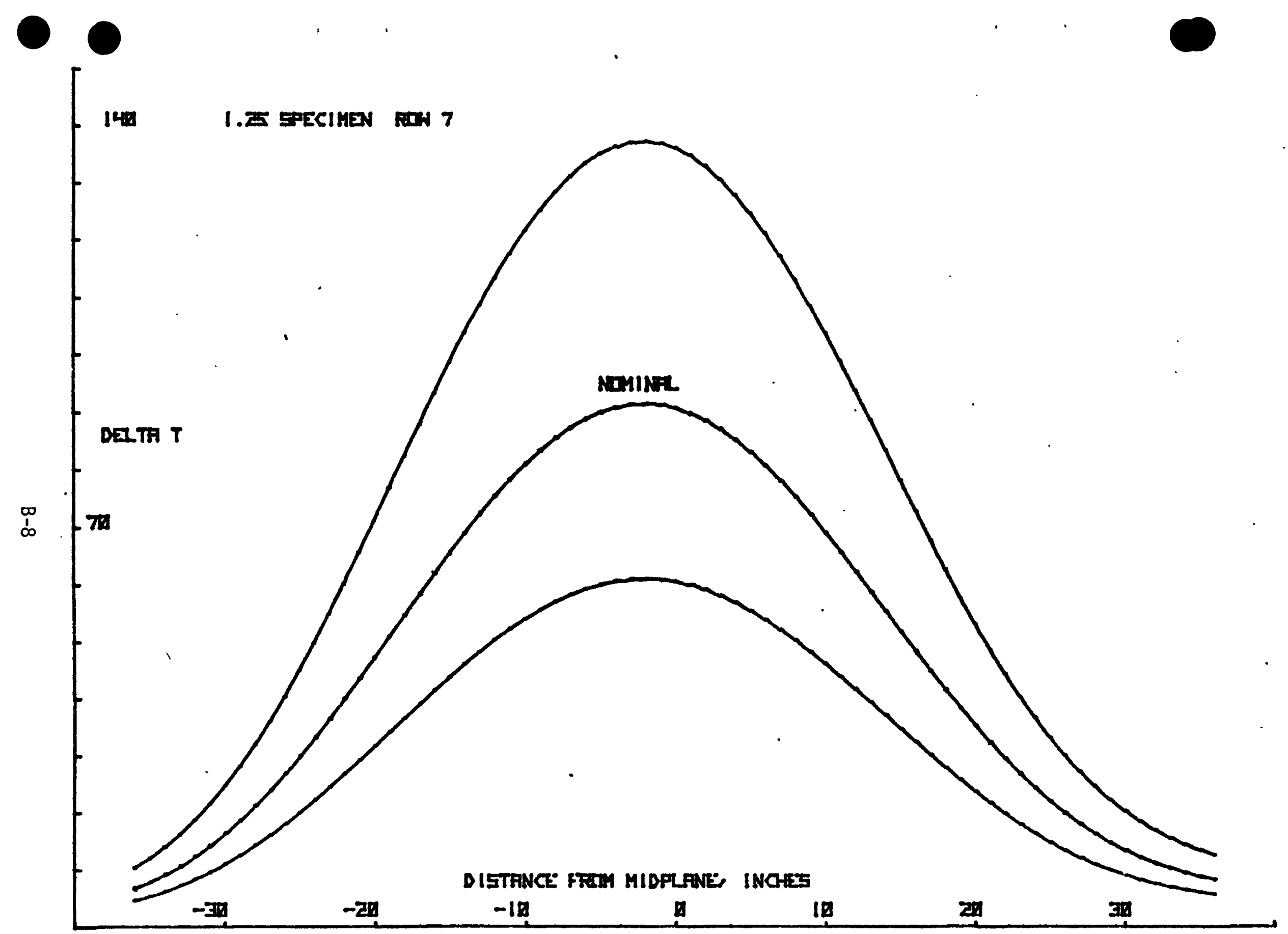

FIGURE 5. $\triangle T$ as a Function of the Distance from Midplane (1.25" Specimen in Row 7 Position). 
APPENDIX C

MOTA DIAGRAMS

C-1 


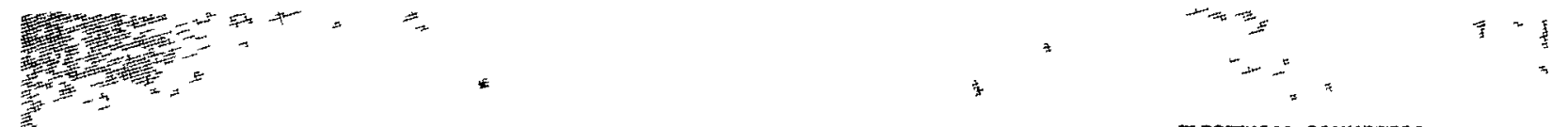

\section{Structural material WX EXPEIMENT}

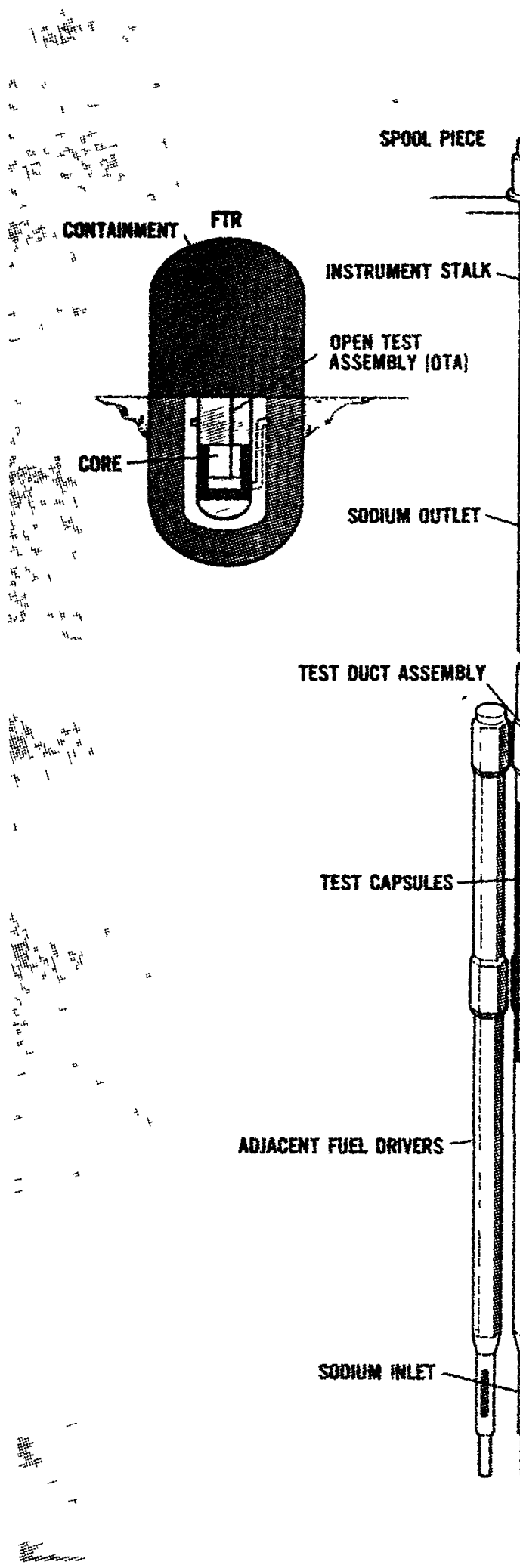




\section{BSME TESTI TRAN}

\section{NCORE SPECMEY CAMISTERS}



GAS EXHAUST LINE

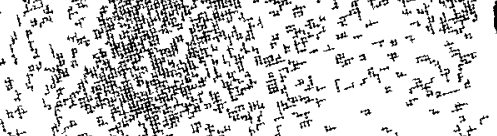

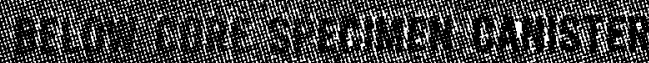




\section{APPENDIX D}

\section{NEUTRON AND GAMMA ENVIRONMENT}

\section{D-1}




\section{CONTENTS}

Users' Guide

$\underline{\text { Page }}$

- FTR Core Map D-3

- Table 1 - Rods Out Neutron Flux D-4

- Table 2 - Rods In Neutron Flux D-5

- Rods 18", Axial Neutron Flux D-6

- Rods Out, Axial Neutron Flux D-7

- Row 6 Gamma Heating D-8

- Midplane Gamma Heating Rate D-9

- Neutron Energy Spectrum D-10

Surveillance Assemblies TDD-1

- Axial Neutron Flux and Energy, Position $2812 \quad 0-11$

- Axial Neutron Flux and Energy, Position 2902 D-12

- Axial Gamma Heat, Position 2812 D-13

- Axial Gamma Heat, Position 2901 D-14

- Core Midplane Neutron Flux D-15

\section{REFERENCES}

The neutron and gamma flux information used in this appendix was taken from two sources.

"Users; Guide for the Irradiation of Experiments in the FTR, " Appendix E, MG-22, Rev. 1, January, 1977

"FTR Surveillance Irradiation Experiment Assemblies HM013, HM014, HM015, and HM016, Test Design Description, Volumes $1 A$ and 1B," TC-829, February, 1977 


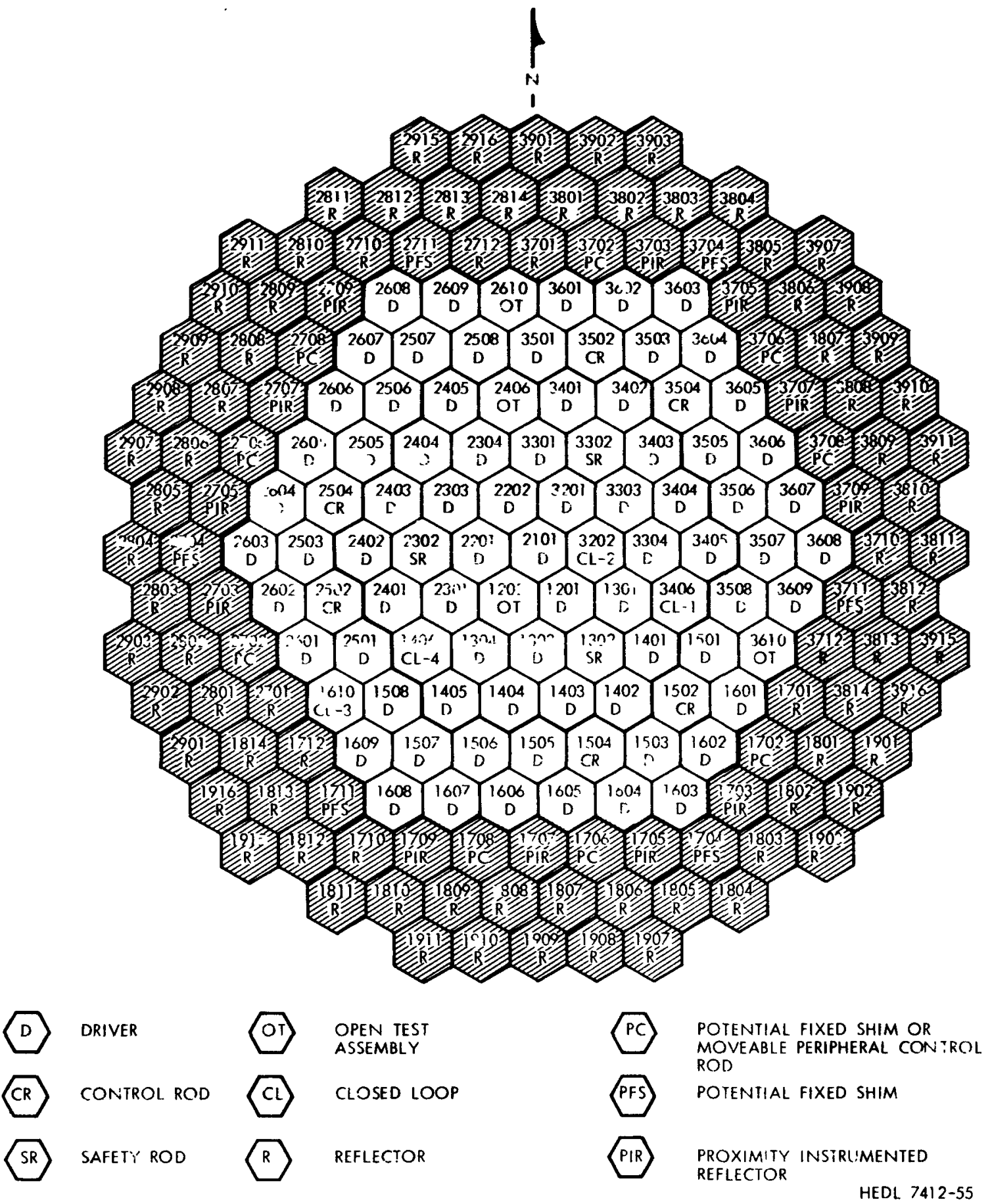

FIGURE 1 (E-I). FTR Core Map. 
TABLE 1 ( $E-I)$

TOTAL FLUX, AND PU-239, PU-240, U-235 and U-238 FISSION RATES AVERAGED BY CORE POSITION, RODS OUT

Core

Position

N101

N201

N202

$\mathrm{N} 301, \mathrm{~N} 303$

N304

$\mathrm{N} 401, \mathrm{~N} 403$

$\mathrm{N} 402$

$\mathrm{N} 404, \mathrm{~N} 406$

N405

N501, N505

$\mathrm{N} 503$

N506, N508

N507

$\mathrm{N} 601, \mathrm{~N} 605$

N602, N604

$\mathrm{N} 603$

N606, N610

N607, N609

N608

N704

N703,N705

N702, N706

N701, N707

N708, N712

N709, N711

N710
( $F$ ission rates in $\mathrm{fis} / \mathrm{sec} / \mathrm{gm}$ )

Pu-239

Fission

Rate

$\left(x^{14}\right)$

.264

.256

.258

.244

.241

Pu-240
Fission
Rate
(x1013)

U-235

Fission

Rate
(x1014)

.577

.278

.271

.555

.274

.525

.529

.259

.255

.465

.432

.511

.485

.231

.217

.233

.224

.429

.373

.444

.416

.201

.328

.311

.263

.334

.327

.272
U-238

Fission Total

Rate Flux

$\left(\times^{12}\right) \quad\left(\times 10^{16}\right)$

.729

.579

.702

.700

.558

.564

.658

.667

.531

.528

.585

.542

.659

.619

.470

.438

.496

.473

$.552 \quad .416$
.178

.197

.178

.480

.582

.550

.407

.389

.325

.430

.412

.339

.364

.419

.386

.173
.162

.142

.165

.141
.328

.308

.261

.317

.317

.266

.142

.191

.217

.223

.220

.195

.145 
TABLE 2 (E-II)

TOTAL FLUX, AND PU-239, PU-240, U-235 and U-238 FISSION RATES AVERAGED BY CORE POSITION, RODS IN

Core

Position

N101

N201

N202

$\mathrm{N} 301, \mathrm{~N} 303$

N304

N401, N403

N402

$\mathrm{N} 404, \mathrm{~N} 406$

N405

N501, N505

N503

N506, N508

N507

N601, N605

$\mathrm{N} 602$, N604 $\mathrm{N} 603$

N606, N610

N607, N609

N608

N704

N703, N705

N702, N706

N701, N707

N708, N712

N709, N711

N710

(Fission rates in $\mathrm{fis} / \mathrm{sec} / \mathrm{gm}$ )

Pu-239

Fission

$\begin{array}{r}\text { Rate } \\ \left(\times 10^{14}\right) \\ \hline\end{array}$

.291

.278

.282

.260

.261

.213

.181

.238

.232

.185

.126

.202

.190

.135

.115

.104

.168

.166

.144
Pu-240

Fission

Rate

$\left(\times 10^{13}\right)$

.658

.624

.621

.580

.593

.478

.405

.562

.543

.449

.300

.504

.471

.301

.252

.216

.360

.360

.311
U-235

Fission

Rate

$\left(\times 10^{14}\right)$

.304

.291

.274

.273

.224

.190

.245

.240

.189

.131

.205

.194

.143

.123

.112

.175

.175

.154
U-238

Fission Total

Rate Flux

$\left(\times 10^{12}\right) \quad\left(\times 10^{16}\right)$

$.845 \quad .642$

$.801 \quad: 610$

.738

.759

.571

.576

.607

.512

.734

.703

.593

.387

.678

.632

.379

.315

.268

.458

.456

.394
.469

.400

.530

.515

.414

.282

.454

.424

.287

.242

.209

.342

.344

.295

.115

.155

.184

.210

.212

.213

.161 


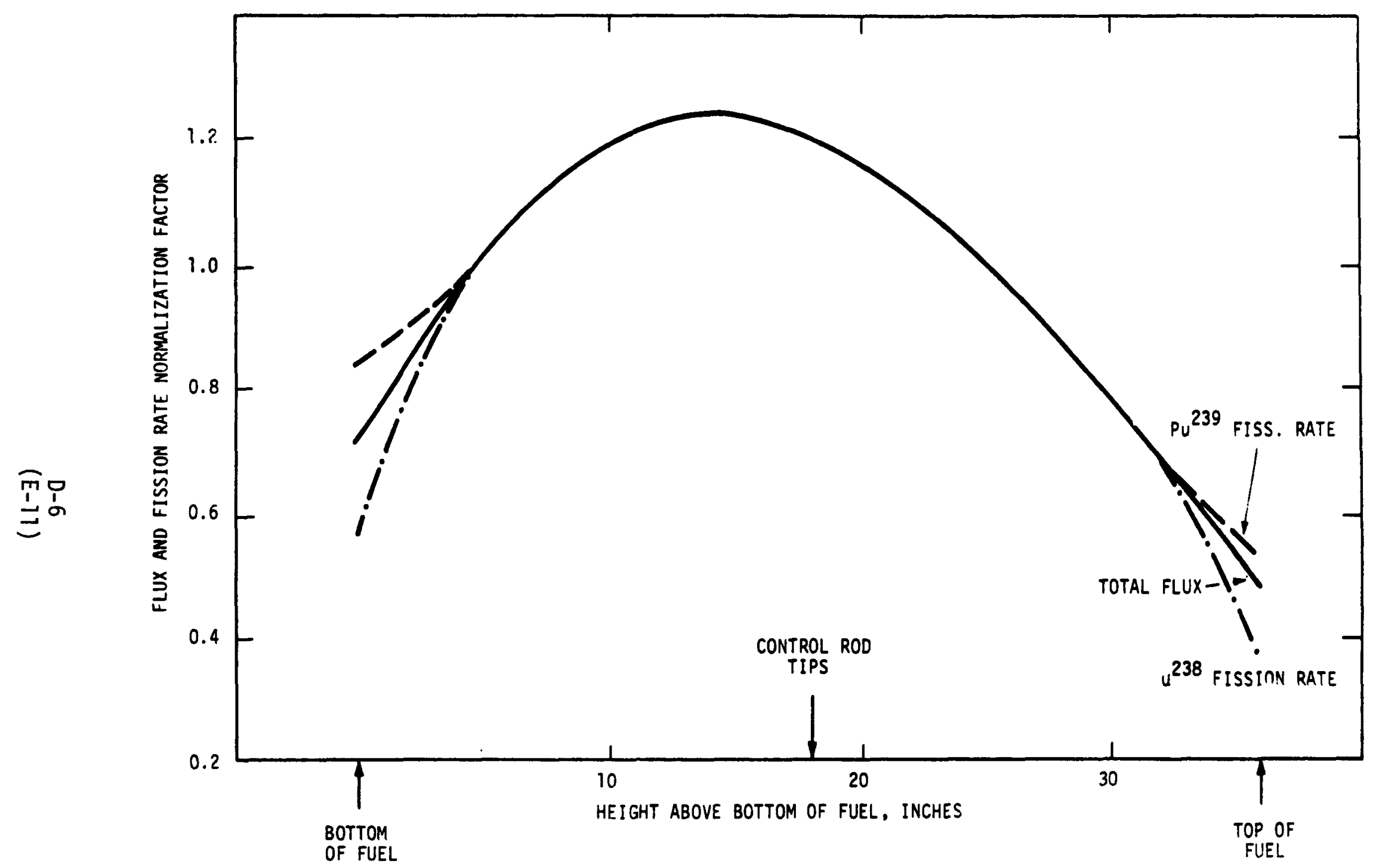

HEDL - 7308-80.3

FIGURE $2(\mathrm{E}-2)$. Axial Flux and Fission Rate Distributions, Rods at 18 Inches. 


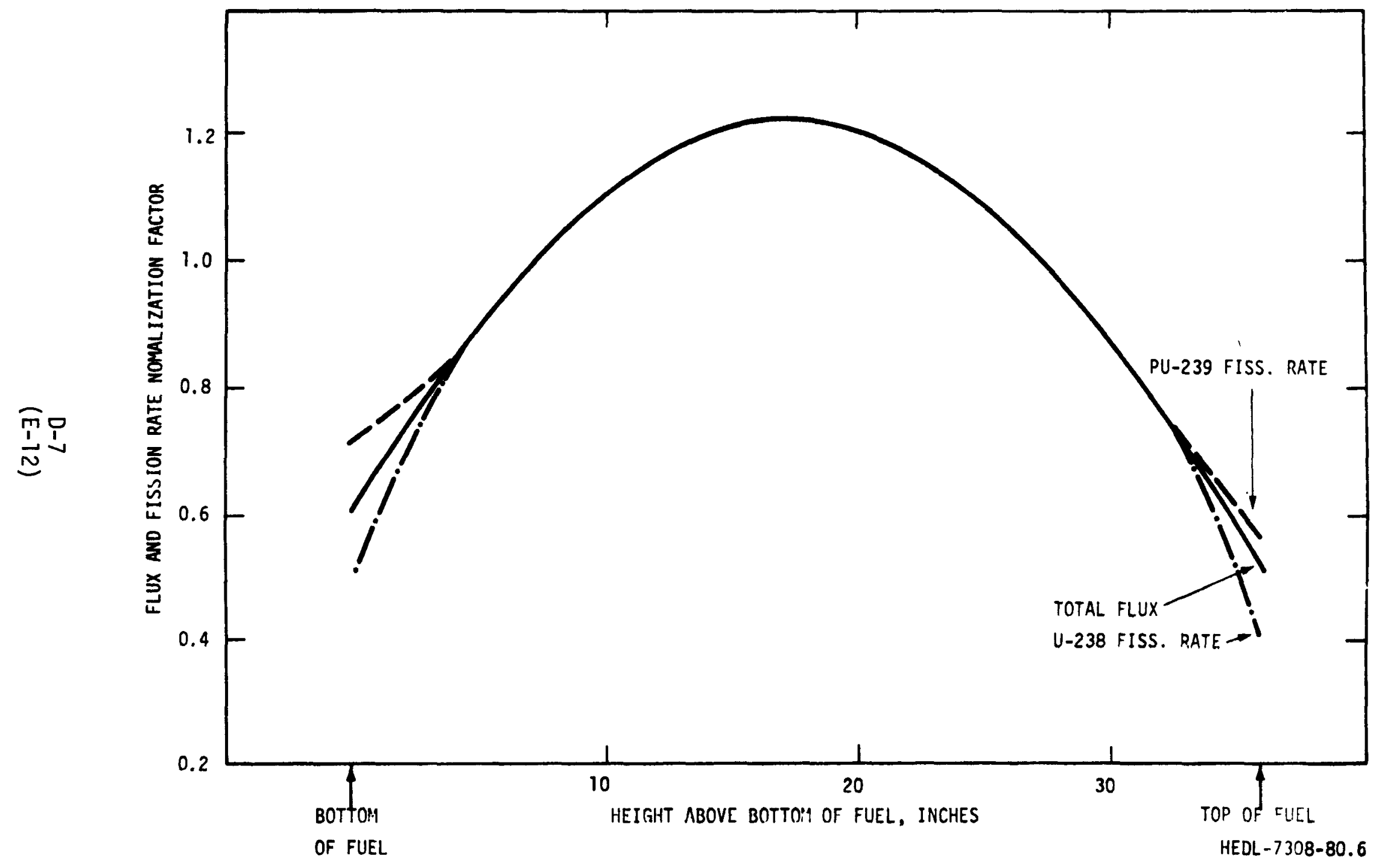

FIGURE $3(\mathrm{E}-3)$. Axial Flux and Fission Rate Distributions, Rods Fully Withdrawn. 


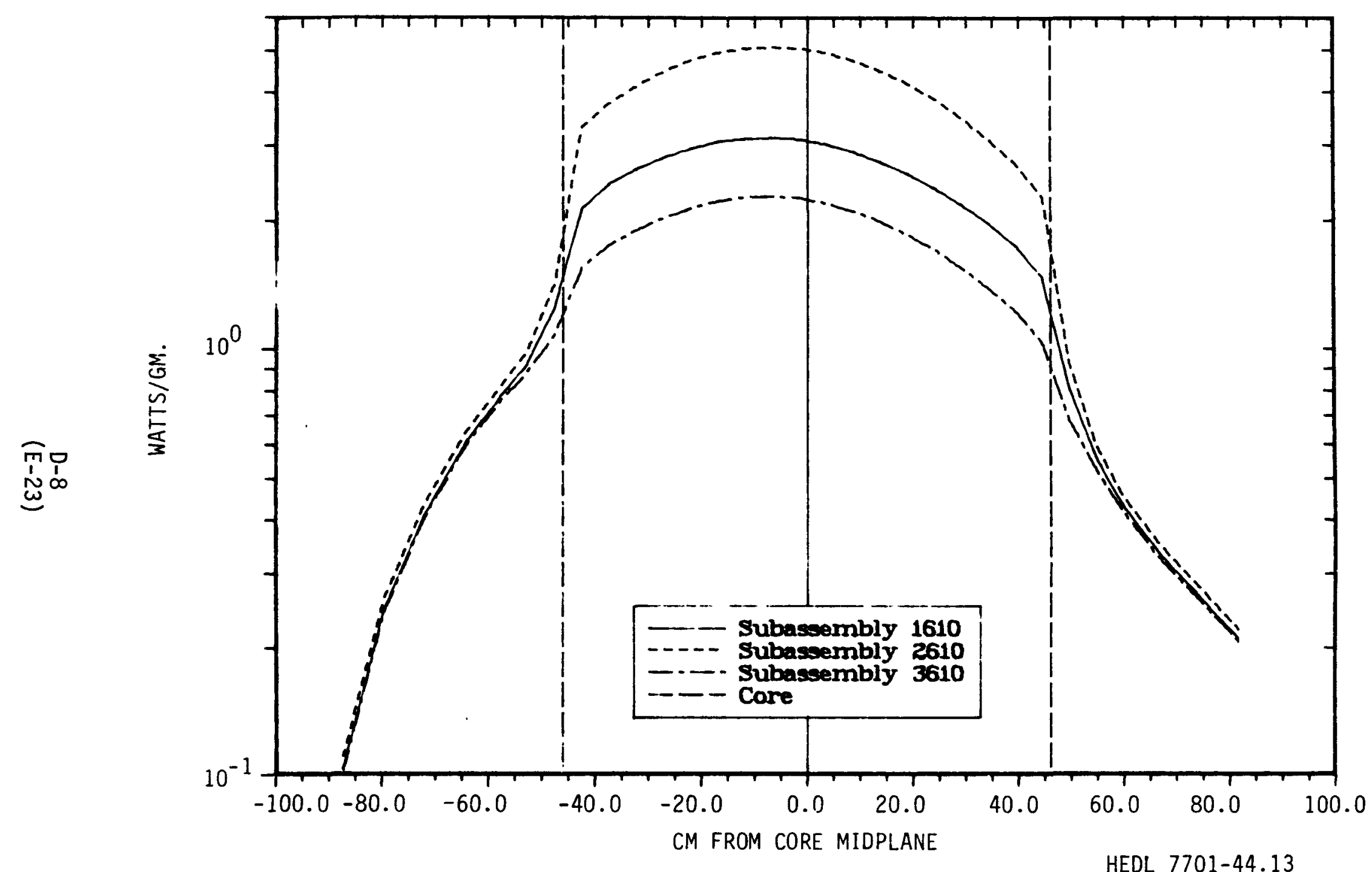

FIGURE 4 (E-14). Stainless Steel Gamma Heating, Row 6. 




HEDL $7701-44.3$

FIGURE 5 (E-18). Midplane Gamma Heating Rate (watts/gram) in Stainless Steel. 


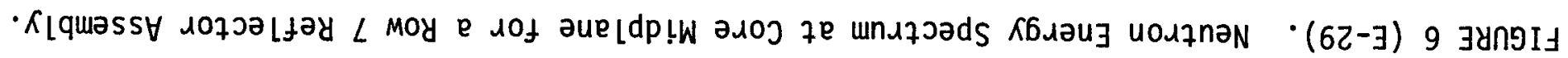

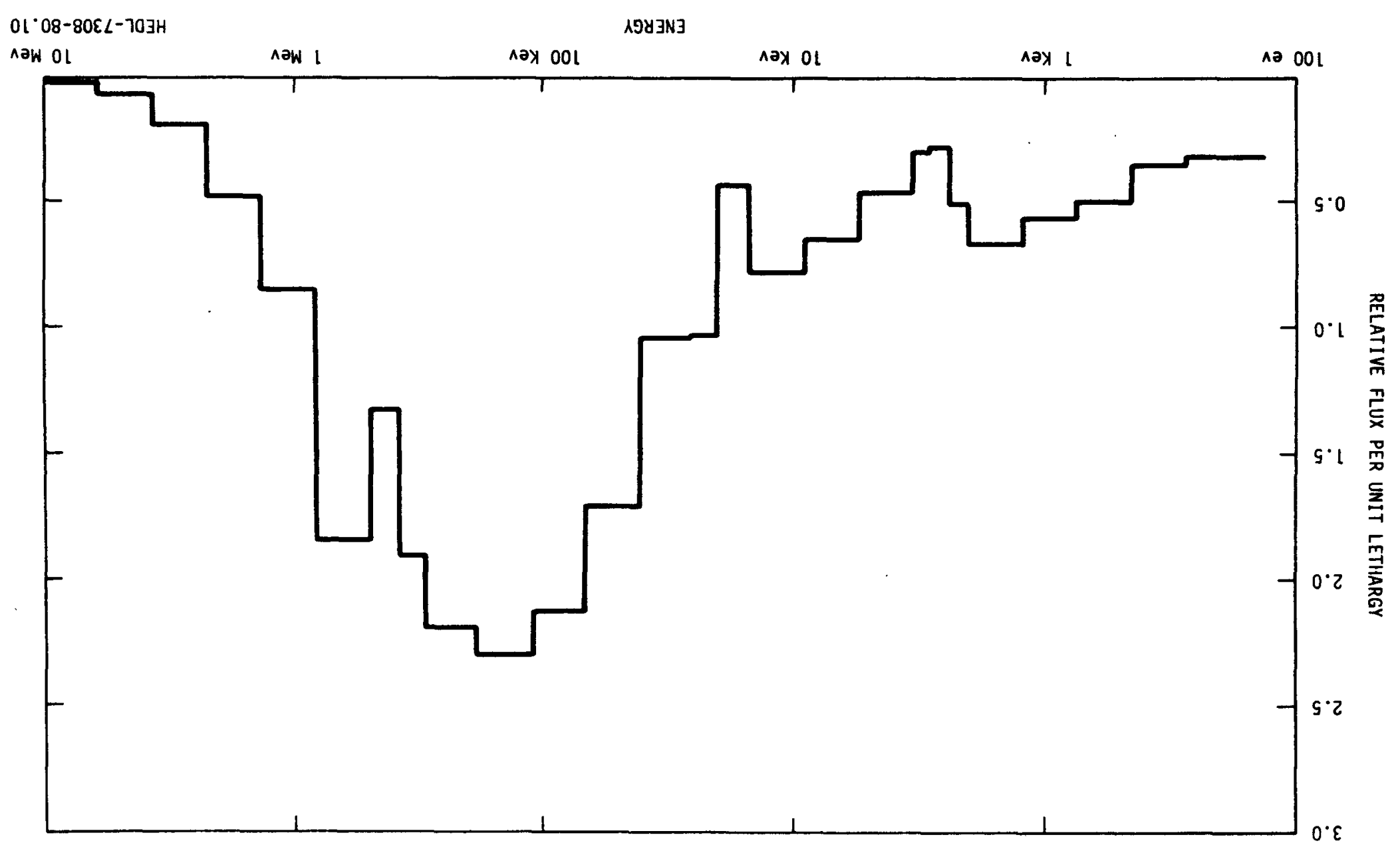






FIGURE 7. Axial Position Flux and Neutron Energy for Radial Reflector Position 2812. 


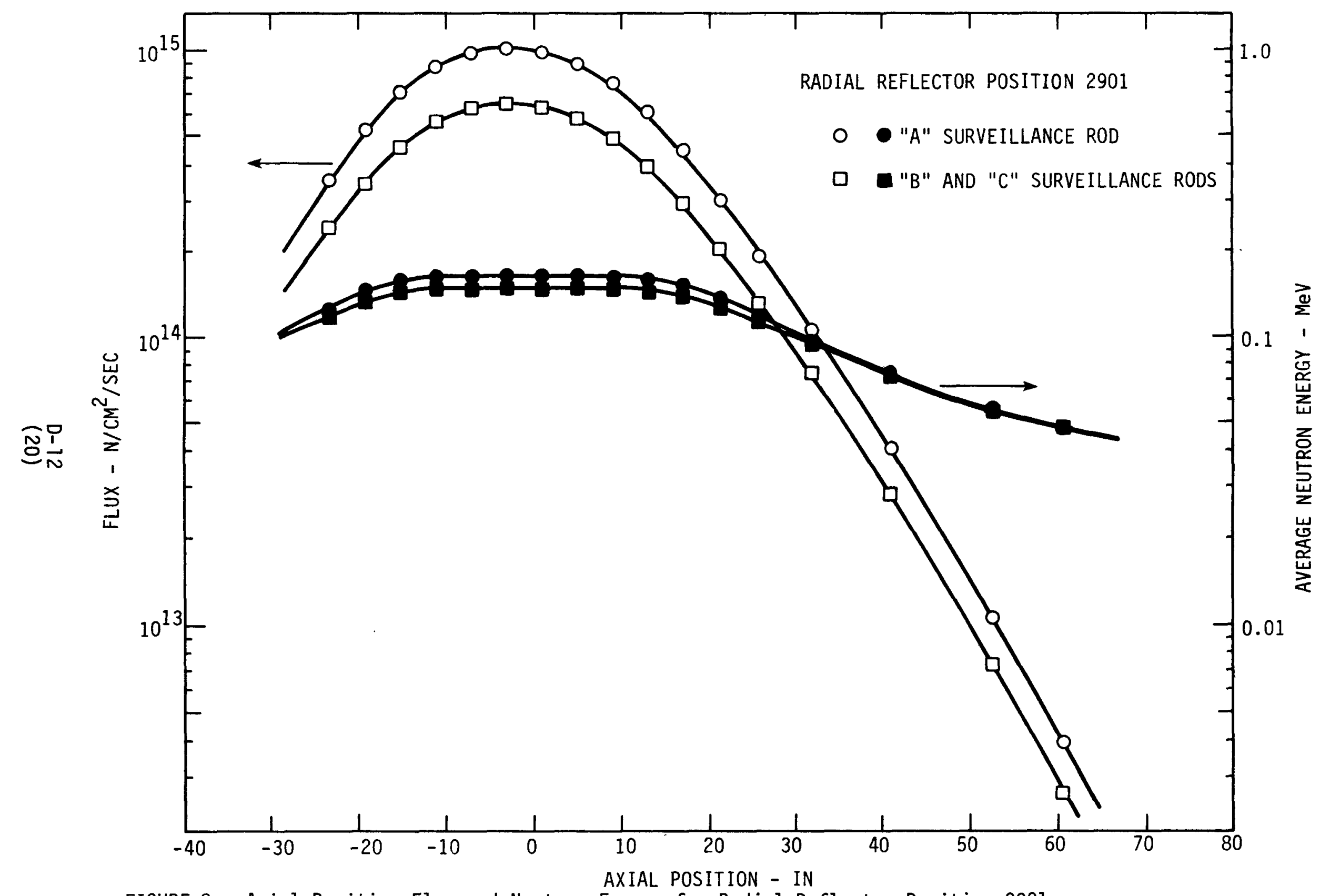

FIGURE 8. Axial Position Flux and Neutron Energy for Radial Reflector Position 2901. 


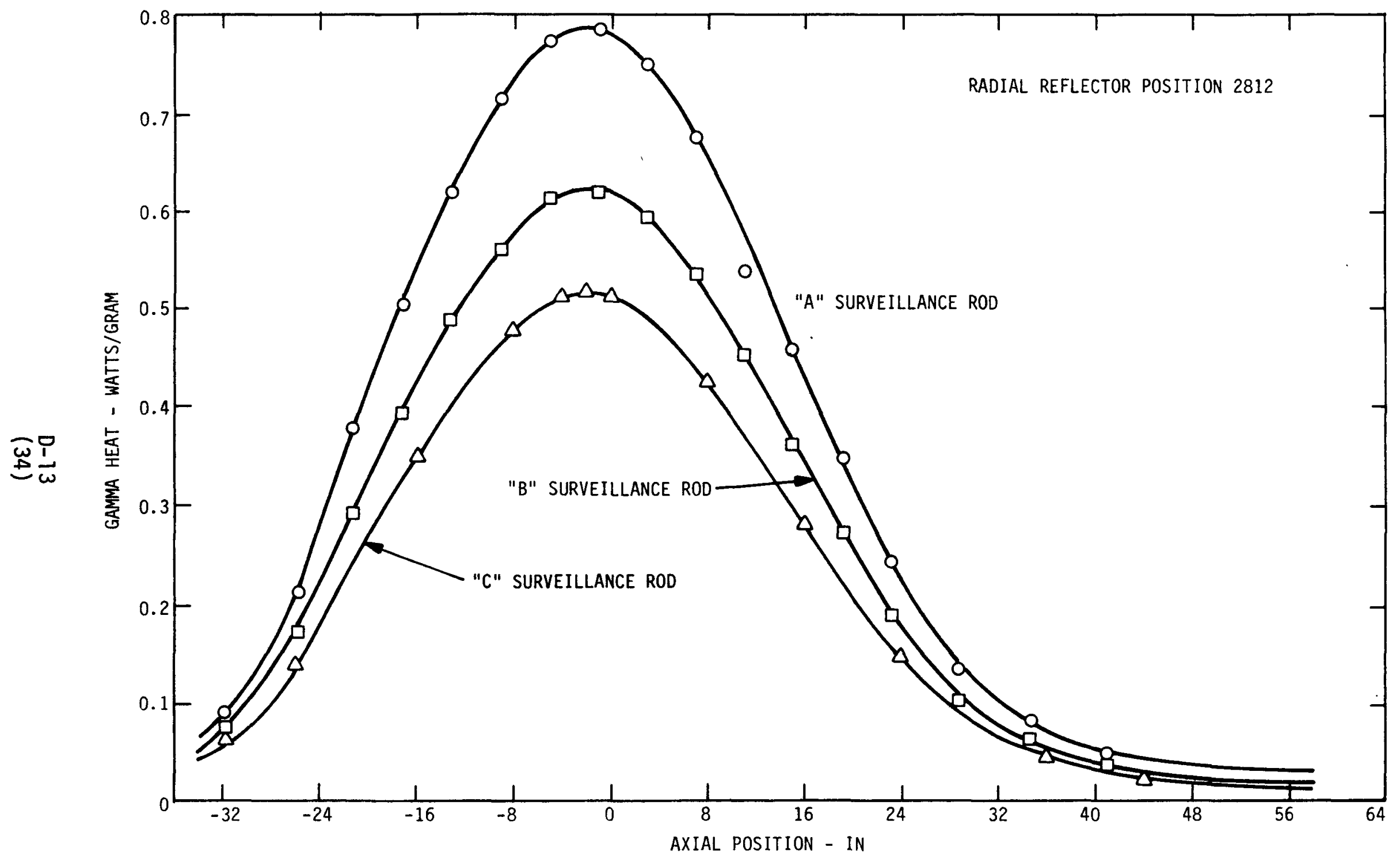

FIGURE 9. Gamma Heat for Axial Location in Radial Reflector Position 2812. 


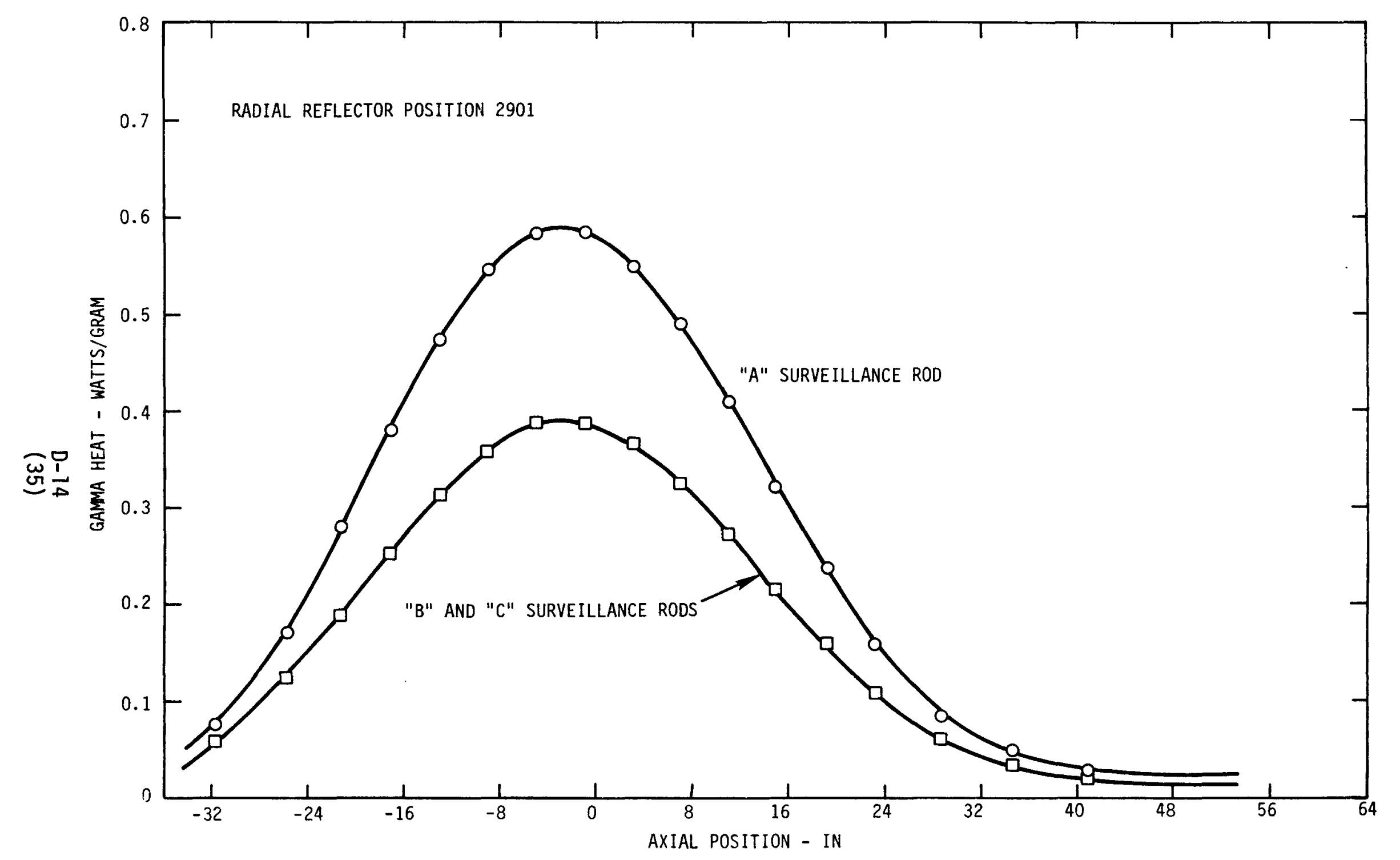

FIGURE 10 (11). Gamma Heat for Axial Location for Radial Reflector Position 2901. 


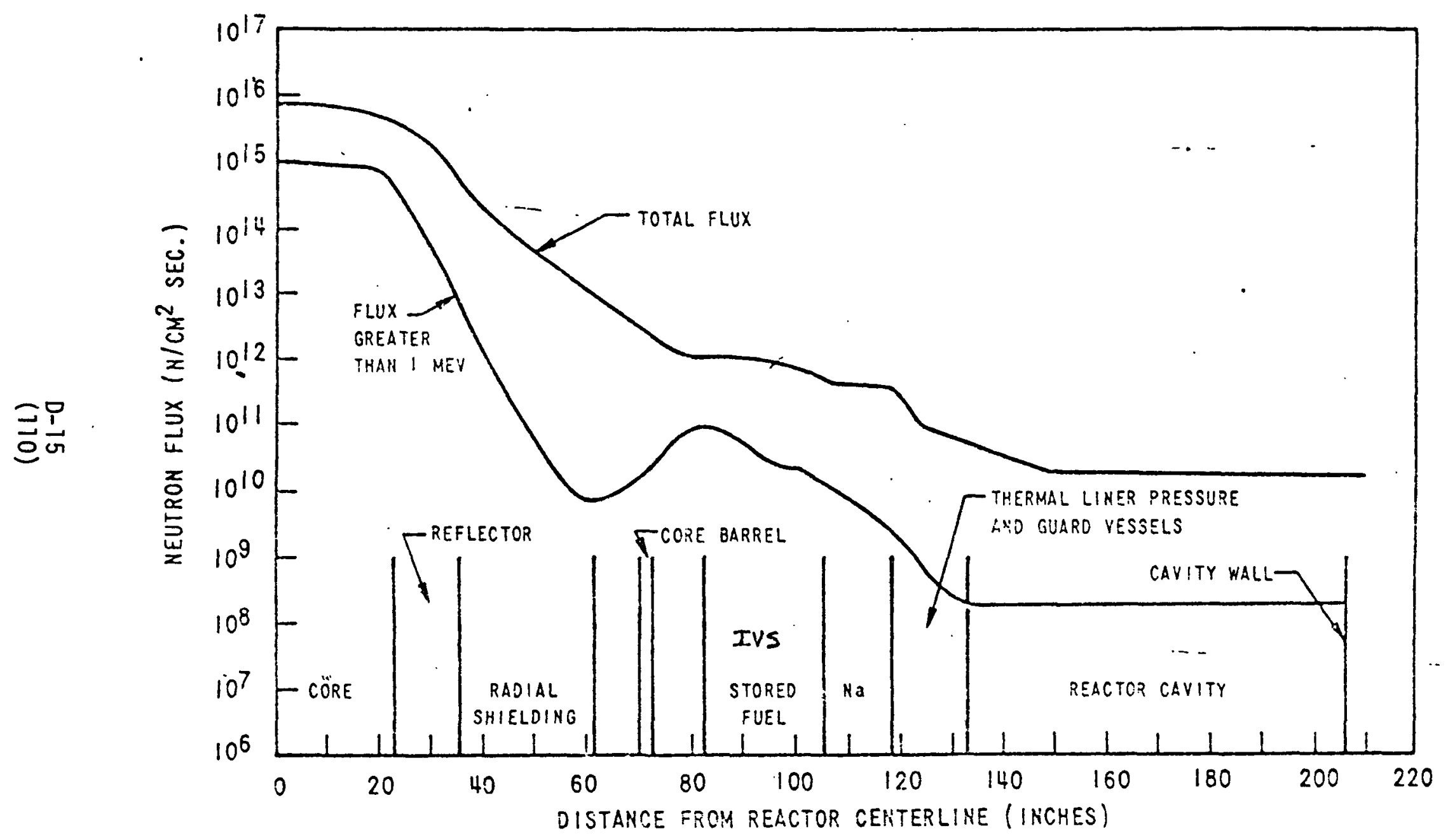

FIGURE 11 (3). Neutron Flux Profiles at Core Midplane. 


\section{APPENDIX E}

STANDARD HARDWARE

E-1 


\section{CONTENTS}

\section{Page}

Photograph of a Reflector Assembly Being Installed

$E-3$ in the Reactor Before the Simulated Fuel Elements Were Installed.

Pictorial - FTR Outer Radial Reflectors

Pictorial - FTR Fixed Shim Assembly

Photograph - Handling Socket

Sketch - Removable Handling Socket

Photograph - Nozzle

$E-8$

Photograph - Nozzle with Shield/Orifice Assembly 
Components Touch Simulated Fuel Assemblies Before Head Closure



\section{FTR OUTER RADIAL REFLECTORS (ROW 8b AND 9 )}



PLATE SUBASSEABLY [USED ALSO FOR WHER ROW Ba REFLECTORS]

$\underset{1}{m}$

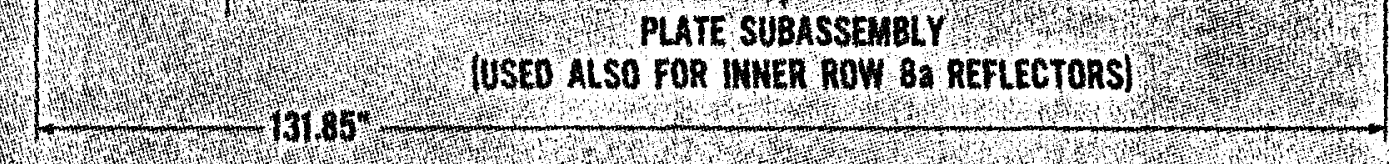

\section{UPPER ADAPTOR BLOCK}

HANDLING SOCKET AND UPPER LOAD PAD

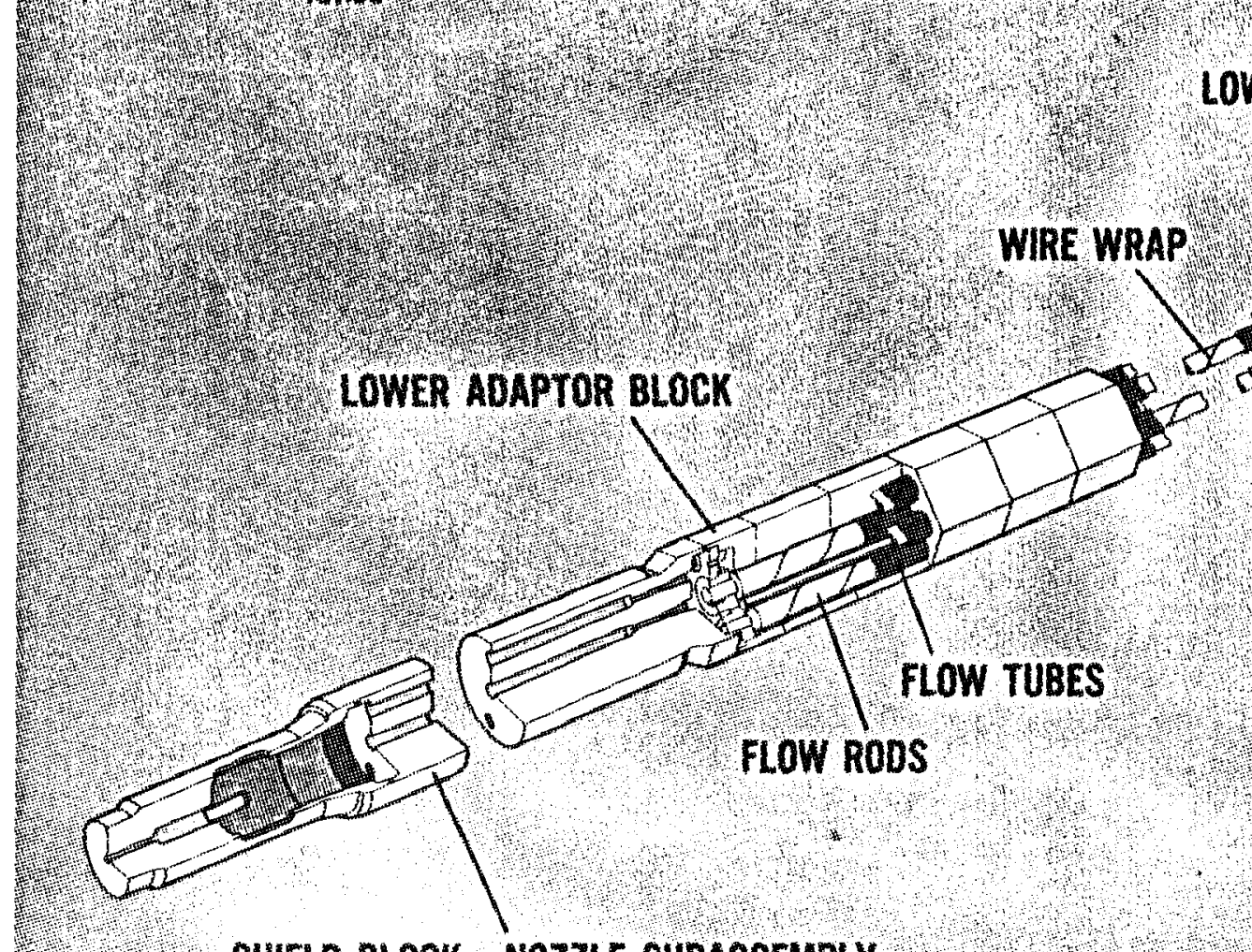

SHIELD BLOCK - NOZZLE SUBASSEMBLY

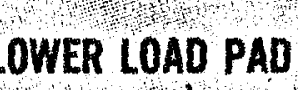

REFLECTOR ASSEMBLY CORE MAP

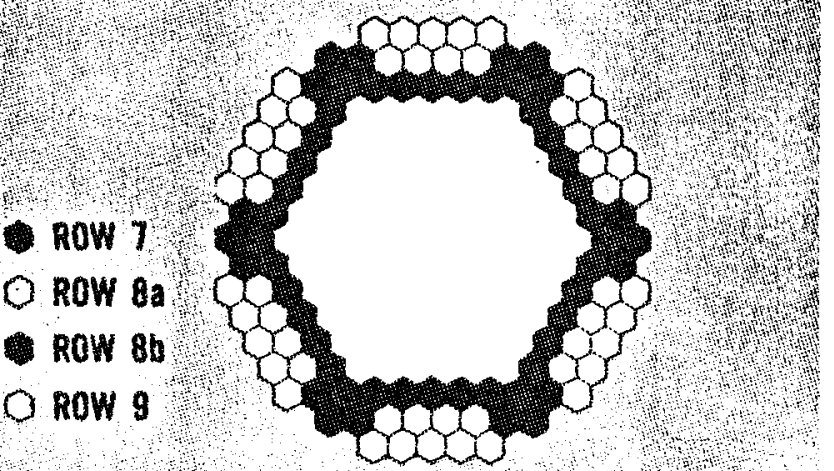




\section{FTR FIXED SHIM ASSEMBLYY}













Removable Handling Socket 


\section{NOZZLE BODY}

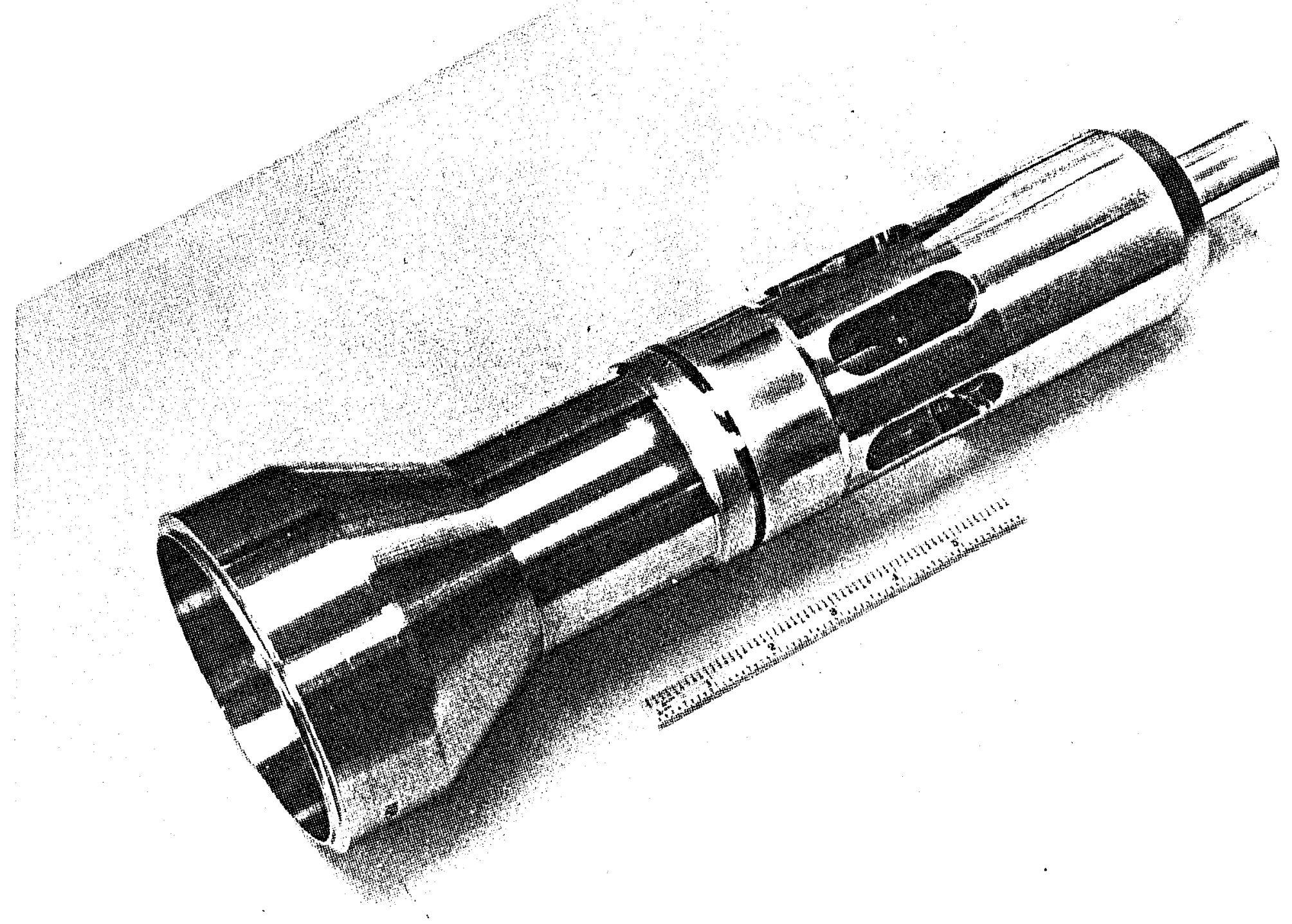




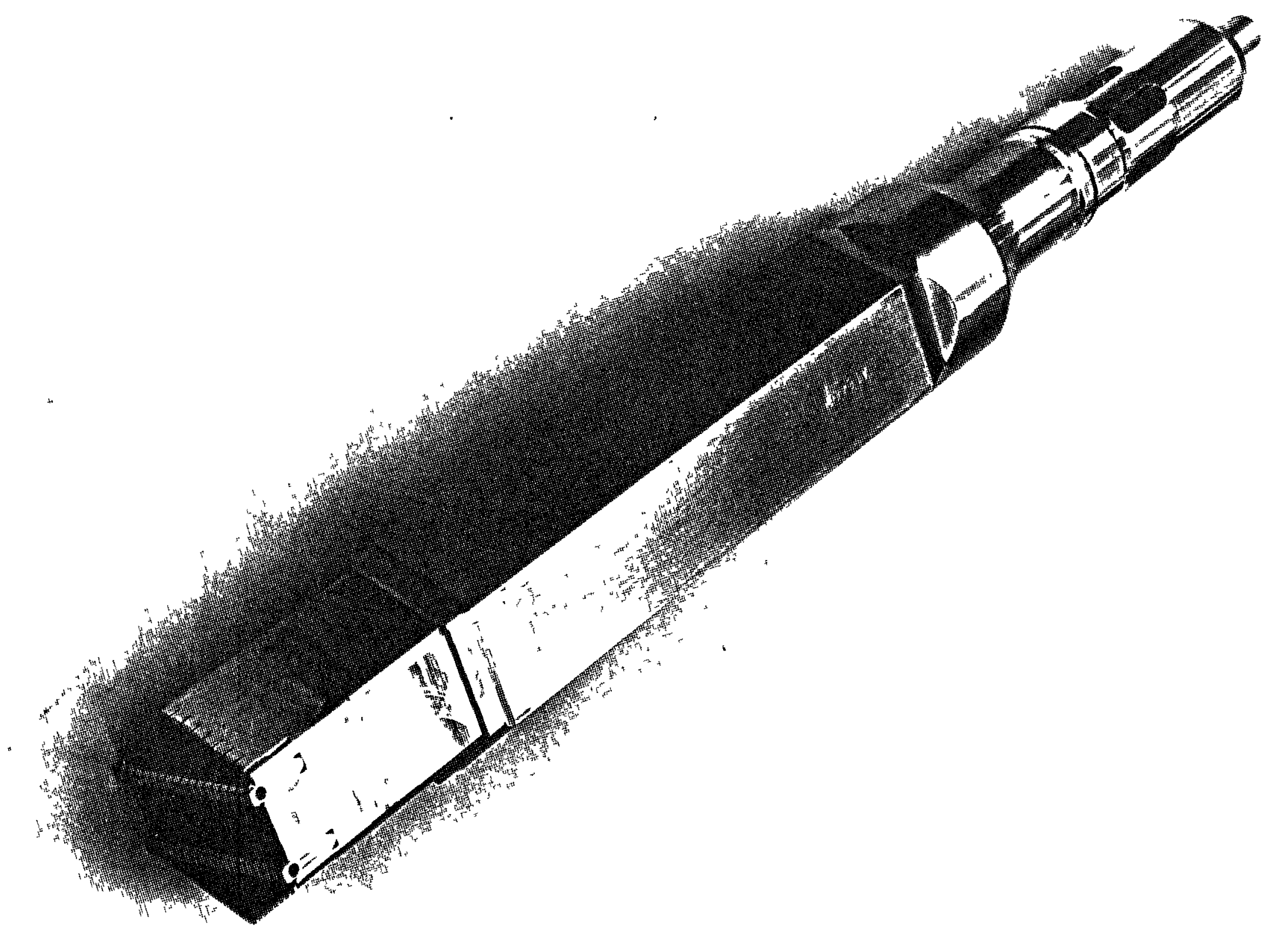






\section{DISTRIBUTION}

Atomics International

J. Page

DOE/FFTFP0

Director (5)

A. R. DeGrazia

DOE/RRT-HQ

Director, Division of Reactor Research and Technology

Asst. Director, Materials Technology

Chief, Materials and Chemistry

Asst. Director, FFTF

Asst. Director for Engineering

Chief, Materials and Structures Branch

Asst. Director, Reactor Projects

Chief, Fast Gas Reactors Branch

A. VanEcho (2)

L. M. Welshans (2)

General Atomics

R. Perkins

S. Rosenwasser

General Electric

N. Hackford

Hanford Engineering Development Laboratory

L. D. B Tackburn

D. C. Corrigan

J. M. Grover

L. A. James (5)

D. C. King (5)

R. L. Knecht (20)

W. J. Mills

A. L. Ward

H. H. Yoshikawa

Correspondence Processing (5)

Document Control

Naval Research Laboratory
D. Miche 1
F. Loss
L. Steele
H. Watson

Oak Ridge National Laboratory

C. Brinkman

W. McAfee

J. Merk le

G. Whitman 


\section{DISTRIBUTION (Cont'd)}

University of Illinois

H. Corten
Westinghouse - Advanced Reactors Division
J. Chang
V. Sazawal
G. Wrights

Westinghouse - R\&D Center

E. Wesse 1

J. Landes 